\title{
NOBLEZA Y PODER EN LA TIERRA DE CUENCA: NUEVOS DATOS SOBRE EL LINAJE ALBORNOZ
}

\author{
José Ignacio Ortega Cervigón ${ }^{1}$
}

\section{RESUMEN}

Este trabajo muestra la evolución del linaje Albornoz y su implantación en la tierra de Cuenca, afianzado en unas bases económicas agrarias propias de la nobleza señorial castellana. Los Albornoz alcanzaron gran poder político y territorial en el ámbito local a lo largo del siglo xIv, y desempeñaron algunos oficios concejiles. A la extinción de la rama principal del linaje, su patrimonio fue repartido entre los Carrillo y los Mendoza, dos de los linajes nobiliarios más importantes en el obispado conquense.

Palabras clave: Nobleza, Castilla, Cuenca, Baja Edad Media, linaje Albornoz.

\begin{abstract}
This article shows the evolution of the lineage Albornoz and their establishment in the tierra of Cuenca, consolidated in some agrarian economic basis typical of the Castilian Nobility. The Albornoz familiy reached great politic and territorial power at the local area along XIVth century, and holded severals council offices. When the principal line lineages was extincted, their patrimony was distributed between Carrillo and Mendoza families, two of the most important nobility lineages in the Cuenca bishopric.
\end{abstract}

Key words: Nobility, Castile, Cuenca, Late Middle Ages, lineage Albornoz.

Desde la reorganización espacial efectuada tras la conquista de la extremadura castellana, a finales del siglo XII, el obispado de Cuenca quedó jurisdiccionalmente dividido por concejos de realengo con amplios alfoces dotados de fuero, como Huete y Cuenca; la Iglesia y las órdenes militares, que recibieron propiedades y algunos enclaves estratégicos; y los miembros de la alta nobleza, que obtuvieron lugares, castillos y heredamientos, aunque sus señoríos no tuvieron continuidad cronológica por tratarse de linajes de la

Fecha de recepción: 30 junio 2009. Fecha de aceptación: 23 septiembre 2009.

1 Departamento de Historia Medieval, Facultad de Geografía e Historia, Universidad Complutense de Madrid, España. Email: jiortegac@gmail.com. 
«vieja nobleza». Durante la Baja Edad Media se acentuó el proceso de nobilización de las tierras de realengo, notoriamente más palpable en las tierras de Cuenca que en las de Huete, en las que solo la configuración del señorío de La Ventosa y la presencia fugaz del linaje Acuña durante la guerra entre Castilla y Portugal tras la entronización de Isabel, supusieron una merma del poder concejil ${ }^{2}$.

El linaje Albornoz fue titular de un extenso patrimonio territorial en la Alcarria y en la Serranía conquenses. El señorío territorial efectivo de la propiedad confería a la nobleza bajomedieval los beneficios económicos, a lo que se sumaba el señorío jurisdiccional, que les concedía el ejercicio de la justicia ante sus vasallos y la percepción de unas rentas, ya que hacían concesiones en censo y arrendamiento ${ }^{3}$.

\section{LA CASA DE ALBORNOZ}

\subsection{Origen del linaje Albornoz y asentamiento en la tierra de Cuenca}

El origen del linaje Albornoz es oscuro, aunque parece proceder de una rama segunda de la casa de Aza, de origen navarro y borgoñón. Gómez García de Aza participó junto a Alfonso VIII en la conquista de Cuenca y, tras el repartimiento que precedió a la toma de Huete, disfrutó de la posesión de la aldea de Albornoz ${ }^{4}$. Su hijo Fernán Gómez pudo iniciar el linaje adoptando el nombre familiar de la villa; a éste le sucedieron Álvaro Fernández - o Álvaro de Moya, según otros autores - y García Álvarez, del que ya tenemos noticias fehacientes de ser cabeza del linaje. Este personaje tenía el señorío de ciertos lugares de la tierra de Cuenca en época del reinado de Alfonso XI, en la que la nobleza comienza su transformación social.

Los Albornoz no pertenecían al grupo de ricos-hombres porque apenas hay una referencia a ellos en las crónicas reales, y ni confirmaban privilegios reales, ni existe constancia de su intervención en la administración cortesana. No obstante, sí obtuvieron una posición dominante en la política urbana de Cuenca, especialmente en la segunda

2 Esta temática fue abordada en nuestra tesis doctoral, La acción política y la proyección señorial de la nobleza territorial en el obispado de Cuenca durante la Baja Edad Media, Universidad Complutense Madrid, 2007. Para el contexto político y económico de Huete en el período bajomedieval son fundamentales los trabajos de SÁNCHEZ

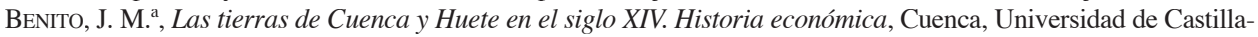
La Mancha, 1994 y Ciudad, Territorio y Poder. Huete y sus aldeas en el s. XV, Cuenca, Alfonsípolis, 2007.

3 Para obtener una panorámica general sobre la nobleza castellana bajomedieval y su dimensión señorial, se pueden consultar, entre otras, las obras de Quintanilla RASO, M. ${ }^{a}$ C., La nobleza señorial en la Corona de Castilla, Universidad de Granada, 2008 y «El estado señorial nobiliario como espacio de poder en la Castilla bajomedieval», en DE LA IGLESIA DuARTE, J. I. (coord.), Los espacios de poder en la España medieval. XII Semana de Estudios Medievales (Nájera, 30 julio-3 agosto 2001), Logroño, Instituto de Estudios Riojanos, 2002 , pp. 245-314.

4 La evolución del linaje Albornoz en Cuenca es conocida por el clásico trabajo de Moxó, S. de, «Los Albornoz. La elevación de un linaje y su expansión dominical en el siglo XIV», en El Cardenal Albornoz y el Colegio de España, vol. I, Zaragoza, 1972, pp. 17-80 y la aportación de Mignot, C., «Evolución de la estructura jurisdiccional en la región alcarreña (siglos XI-XV)», Hispania, XLVI/163 (1986), pp. 245-281. Desde el trabajo del profesor Moxó no ha aparecido, al menos de forma monográfica, ninguna investigación centrada en el linaje Albornoz, por lo que trataremos de añadir a su línea básica argumental los nuevos datos extraídos de las fuentes archivísticas consultadas. 
mitad del siglo XIV. En el panorama político castellano adoptaron una postura de firme apoyo a Enrique de Trastámara y se beneficiaron de las mercedes concedidas una vez entronizado.

García Álvarez disfrutó del señorío jurisdiccional de Albornoz y Naharros —en la llanura conquense - y Uña, Valdemeca, Aldehuela, Cañizares, el Hoyo de Cuenca, Ribagorda, Poyatos, Portilla, Valdecabras, Valsalobre, Sacendocillo, Arrancacepas y Villaseca - en la serranía conquense- - También poseía entonces minas y pozos de sal en Valsalobre y Beamud, adquiridos por trueque con el cabildo catedralicio de la ciudad; asimismo, la heredad de Sotoca, cercana a Sacedoncillo, fue adquirida por compra. Otros heredamientos tuvieron en Villar de Olalla, Valera de Suso y Yuso, Mezquitas y en la tierra de Moya. Aparte de los lugares mencionados, el linaje poseyó en propiedad bienes como la laguna de Palomera, la dehesa y casa de la Vivera, la casa de Ballesteros, la de Villar de Tejas, la de San Lorenzo de la Parrilla, la casa y heredades de Sotos, Campo-Robles, El Campillo y Belinchón, así como las adquiridas por Álvar García el Joven en Ribatajada y Esteras.

En 1369 el rey Enrique II le donó la villa de Utiel, que le permitió engrandecer el patrimonio con bienes territoriales, rentas y tributos. Esta donación respondió también a intereses de vigilancia de defensa de la frontera oriental de Castilla frente a Aragón. Este monarca confirmó también las anteriores donaciones de Alfonso XI — Torralba y Tragacete - y la compra de Beteta efectuada a Leonor de Guzmán, añadiendo la merced de Moya, de gran riqueza maderera. La posesión efectiva de todos estos lugares fue lograda por su hijo Micer Gómez de Albornoz.

El matrimonio de García Álvarez con Teresa de Luna, cuya familia poseía señoríos cercanos a la frontera castellana, reportó al linaje un notable ascenso social.

Los hermanos Álvar García y Fernán Gómez, hijos de García Álvarez, lucharon por el monarca Alfonso XI en la tierra de Cuenca frente a don Juan Manuel, tras la ruptura del compromiso matrimonial entre el monarca y la hija de éste, doña Constanza 5 .

\subsection{La evolución del linaje en los siglos $\mathrm{XIV} \mathrm{y} \mathrm{XV}^{6}$}

\section{Garci Álvarez de Albornoz († 1328)}

Garci Álvarez de Albornoz fue el IV señor de Albornoz, Uña, Valdemeca, Aldehuela, el Hoyo de Cuenca, Cañizares, Mezquitas y Valera. Fue alcalde de la fortaleza de Huélamo, que pertenecía a la encomienda de Santiago, durante los últimos años de su vida. Fue tutor de Alfonso XI de Castilla y de su hijo, el infante Sancho. Participó en la batalla del Salado. Falleció el 18 de septiembre de 1328 y está sepultado en la catedral de Cuenca. Se unió en matrimonio con Teresa de Luna, que falleció en 1362, hija de don Gómez de

\footnotetext{
5 Moxó, S. de, ob. cit., p. 35.

6 Hemos de advertir que la confección del cuadro genealógico del linaje Albornoz resulta controvertida, pues las fuentes consultadas son dispares y, en algunos casos, confunden determinados nombres y personajes. Se pueden consultar algunos de estos datos en la obra de los hermanos García CARrafFA, A. y A., Diccionario heráldico y genealógico de apellidos españoles y americanos, Madrid, Imp. Antonio Marzo, 86 vols., 1920-1963, en la de MÁrtir Rizo, J. P., Historia de la muy noble y leal ciudad de Cuenca, Madrid, 1629, pp. 251-257, y en la citada de Salvador de Moxó.
} 
Luna — nieto del infante don Jaime - y hermana de Jimeno de Luna — arzobispo de Toledo - , Pedro de Luna — ricohombre aragonés - y Juan de Luna — padre del papa Luna - . Tuvieron cuatro hijos, de los que Álvar García de Albornoz siguió la línea.

Fernán Gómez de Albornoz, señor de Campo-Robles, Pedraza, Villoria, Merinos y Arcos, fue General de la Frontera de Requeja en 1337, Comendador Mayor de Montalbán y de Mestanza y Trece de Santiago; entre 1329 y 1359 fue alcalde del castillo de Huélamo. Acompañó a su hermano Álvar García en 1329 en la oposición de don Juan Manuel; en 1331 se halló en la coronación de Alfonso XI y fue armado caballero por el monarca; en 1352 participó en el sitio de Algeciras. Pasó los últimos años de su vida en el reino de Aragón 7 . La documentación concejil de Cuenca menciona a Gonzalo Fernández de Albornoz como señor de Beamud en 1390, a la muerte de Juan de Albornoz. Cronológicamente podría ser este personaje que recoge García Carraffa, pero no podemos argumentarlo fehacientemente. Del mismo modo, Garci Álvarez de Albornoz, que aún vivía en 1382, tuvo un hijo llamado de forma homónima y que podría ser el personaje que llegó a ser guarda mayor de Cuenca al comienzo del siglo xv, identificado más adelante como hijo ilegítimo de Micer Gómez García de Albornoz. Ambas versiones, a priori, podrían encajar por fecha. Según esta interpretación, Gonzalo Fernández de Albornoz y Garci Álvarez de Albornoz serían tío y sobrino respectivamente. Un documento, en el que aparecen como testigos de la carta de poder del concejo de Cuenca al regidor Matías Sánchez para que tomara parte en los apeos de términos con los señoríos de la sierra, puede dar fe de su coetaneidad. También hay constancia de una provisión real de Juan II en un pleito entre María Rodríguez, hija de Teresa Gómez de Albornoz, y el concejo de Cuenca por el cobro del pecho de la cabeza de los judíos. Pedro Martínez, marido de Teresa Gómez de Albornoz, había recibido como merced en tiempos de Enrique II 5.000 mrs. en el pecho de la cabeza de los judíos, confirmada sucesivamente por Juan I y Enrique III. Su hija María Rodríguez Mejía, casada con Alfonso Yáñez Fajardo, vecino de Murcia, reclamó esta cantidad como heredera legítima, una vez que su madre había fallecido y había dejado de cobrar la merced «desdel tienpo que la dicha judería de Cuenca fue destroyda e desfecha por el dicho conçejo», que había hecho «tornar christianos por fuerça a los judíos de la dicha çibdat de Cuenca». La sentencia fue desfavorable a María Rodríguez al considerar que su demanda no había sido probada. El concejo, que se escudaba en no pagar esa merced al no existir aljama en Cuenca, había negado participar en la destrucción y saqueo de la judería, si acaso fueron personas particulares - y entre ellas figuraría el padre de María, Ruy González Mejía - y que su acción personal, según la ley de ordenamiento, prescribía a los diez años ${ }^{8}$.

7 Fue padre de Gonzalo Fernández de Albornoz, Catalina Fernández de Albornoz, Urraca Fernández de Albornoz — señora de Fuentesbuenas - , Teresa Gómez de Albornoz, Garci Álvarez de Albornoz — que siguió la línea - y Pedro Gómez de Albornoz — cardenal de Santa Práxedes en 1374, hijo ilegítimo-, según la versión de García Carraffa.

8 Los distintos documentos citados están fechados, respectivamente, en Cuenca, 17 julio 1390, Beamud, 23 agosto 1390, Guadalajara, 15 mayo 1408, y Rámaga, 13 julio 1414, A(rchivo) M(unicipal) (de) C(uenca), publ. Chacón Gómez-Monedero, A., Colección diplomática del Concejo de Cuenca, 1190-1417 [en adelante Colección...], Cuenca, 1998, docs. 130, 131, 187 y 202, pp. 300, 315, 432-434 y 477-484. María Rodríguez fue condenada a pagar las costas del pleito, que ascendían a $3.914 \mathrm{mrs}$. 
Gil Álvarez de Albornoz (1310-1367) fue el personaje del linaje que alcanzó mayor prestigio y resonancia en la época, al realizar una gran carrera política y eclesiástica, especialmente en la península itálica: fue arcediano de Calatrava, Arzobispo de Toledo en 1337, Cardenal de Santa Sabina en 1351 y fundador del Colegio Español de Bolonia. El papa Clemente VI le dio el capelo en Aviñón en $1351^{9}$.

Fernando de Albornoz fue Arzobispo de Sevilla.

\section{Álvar García de Albornoz († 1374)}

Álvar García de Albornoz el Viejo fue el V señor de Albornoz, señor de Utiel, Moya, Torralba y Beteta. Ocupó el cargo de mayordomo mayor de Enrique II y fue tutor del infante Sancho. También fue embajador de Alfonso XI en Francia para tratar la boda de Blanca de Borbón con el futuro Pedro I, con la que casó por poderes, y la acompañó a Valladolid; fue copero mayor de estos monarcas, oficio que desempeñaron otros miembros del linaje durante el siglo xIV. En 1356 estuvo exiliado en Aragón, en el contexto de la denominada Guerra de los Dos Pedros. Previamente, el rey castellano Pedro había concedido el perdón a la ciudad de Cuenca y a quienes tomaron parte en la sublevación a favor de la reina doña Blanca, su mujer, entre los que se encontraba Alvar García ${ }^{10}$. Los bienes de Álvar García de Albornoz y de Fernán Gómez estaban expropiados, y en parte se trataron de vender al cabildo catedralicio de Cuenca, que se resistía. El monarca Pedro I envió una carta para que los justicias no apremiaran a los clérigos a comprar dichos bienes ${ }^{11}$. Murió en 1374 y está sepultado en el panteón familiar de la catedral conquense, en cuya lápida sepulcral se lee que «dexó de si muchas buenas fazañas e finó XXVIII días de junio. Era de MCCCCXII años».

Contrajo matrimonio con Teresa Rodríguez, que era hija de Rodrigo Álvarez de Asturias, señor de Noroña o, según otros autores, de Ruy Páez de Sotomayor, justicia mayor del monarca Sancho IV. Fueron padres de Gómez García de Albornoz, el primogénito.

Violante de Albornoz fue la segunda hija, casada con Ruy Pérez, pero no tuvieron descendencia.

Álvar García de Albornoz el Joven fue señor de Utiel, Beteta y Tragacete, además de ejercer el oficio cortesano de copero mayor de los monarcas Enrique II y Juan I. Murió en verano de 1385, en la batalla del Troncoso frente a los portugueses. Contrajo matrimonio dos veces: la primera con doña Elvira Álvarez y la segunda con doña María de

9 MÁRTIR Rizo, J. P., ob. cit., p. 253. Su vida política y eclesiástica ha sido analizada en diversas obras, entre otras, BENEYTo PÉREZ, J., El cardenal Albornoz, canciller de Castilla y caudillo de Italia, Madrid, EspasaCalpe, 1950; Verdera y Tuells, E. (ed.), El Cardenal Albornoz y el Colegio de España, Studia Albornotiana, XI-XII-XIII (1972-1973); SÁEZ, C., «El Cardenal Gil de Albornoz y los beneficios eclesiásticos en EmiliaRomaña (1353-1367)», En la España Medieval, 1 (1980), pp. 423-442; Trenchs OdenA, J., «La familia y comitiva de Albornoz (1302-1353)», Italica: cuadernos de Trabajos de la Escuela de Historia y Arqueología en Roma, 15 (1981), pp. 165-178.

10 Real sobre Toro, 4 noviembre 1355, SANZ y DíAZ, C., Reseña cronológica de algunos documentos conservados en el archivo de la Catedral de Cuenca, Cuenca, 1965, doc. 440, p. 52. También fueron perdonados Fernán Gómez, García Álvarez y Gómez García de Albornoz.

11 Sevilla, 12 diciembre 1358, ibidem, doc. 461, p. 54 y SÁnChez Benito, J. M. ${ }^{\text {, }}$ Las tierras de Cuenca y Huete en el siglo XIV. Historia económica, ob. cit., pp. 68-69. 
Castilla, hija del conde don Tello, señor de Vizcaya y hermano de Enrique II. Al no tener descendencia, le sucedió su sobrino Micer Gómez ${ }^{12}$. En su testamento dispuso que le enterraran en la capilla de su abuelo don García Álvarez, a la espalda de su padre Álvar García el Viejo.

Urraca de Albornoz fue la cuarta hija, señora de Portilla, Valdejudíos y Navahermosa, y casada con Gómez Carrillo el Viejo, señor de Ocentejo y Paredes, alcalde mayor de los hijosdalgo de Castilla y ayo del rey Juan II. El linaje Carrillo de Albornoz nació, por lo tanto, de la fusión de una rama de los Carrillo y los Albornoz por esta unión matrimonial ${ }^{13}$. La creación de esta rama de los Carrillo respondía a una estrategia matrimonial establecida por los criterios de crear una red geográficamente extensa e impedir la fragmentación del patrimonio a través de la alianza con otro linaje del entorno conquense ${ }^{14}$.

María Álvarez de Albornoz fue señora de Villoria y casó con Juan Alfonso de la Cerda, señor de Sandoval entre otros lugares, ricohombre de Portugal y Castilla, mayordomo mayor del infante don Fernando, después rey de Aragón ${ }^{15}$.

Por último, Teresa de Albornoz se unió en matrimonio con Juan Martínez de Luna, señor de Illueca, Gotor, Alfaro, Cornago y Jubera, ricohombre de Aragón y Castilla.

Alvar García de Albornoz incluyó en su testamento una cláusula por la que ordenaba que los lugares de Beteta y Utiel con todas sus aldeas y términos pasaran a su hijo Alvar García, quien a su vez dispuso su mayorazgo en presencia de su hermano Micer Gómez de Albornoz ${ }^{16}$. El infante don Pedro de Aragón, marqués de Villena, obtuvo la licencia de

12 Gutiérrez Coronel, D., Historia genealógica de la Casa de Mendoza, t. I, Biblioteca Conquense, v. III, Instituto Jerónimo Zurita del CSIC y Ayuntamiento de Cuenca, 1946, pp. 44-46.

13 Los Carrillo de Albornoz alcanzaron gran protagonismo en la política urbana y territorial de Cuenca, especialmente en la segunda mitad del siglo XV, desde la titularidad del señorío de Torralba y Beteta. Entre otros trabajos que recogen datos sobre la genealogía e intereses de los Carrillo de Albornoz, podemos citar los de Carrillo Laso de Guzmán, A., Epítome del origen y descendencia de los Carrillo, Lisboa, 1639; Luis SalazAr y CAStro, Historia genealógica de la Casa de Lara, Madrid, 1697, III; PAnZÁn, L., Recordanzas en tiempo del Papa Luna (1407-1435), ed. de Gregorio de Andrés, Madrid, Fundación Universitaria Española, 1987, pp. 233-252; Mignot, C., ob. cit.; Quintanilla Raso, M. ${ }^{\text {a }}$ C., «Marcos y formas de proyección de la nobleza conquense en su entorno urbano y territorial», en Congreso Internacional de Historia. El Tratado de Tordesillas y su época, Valladolid, Junta de Castilla y León, 1995, I, pp. 144-146; Ávila SEOANE, N., «Los señores medievales de Ocentejo y Valtablado del Río en el concejo de Medinaceli», Miscelánea Medieval Murciana, XXXI (2007), pp. 23-37; Ortega CERvigón, J. I., «Crónica de un fratricidio. El linaje Carrillo de Albornoz en la tierra de Cuenca durante la baja Edad Media», Castilla y el mundo feudal. Homenaje al prof. Julio Valdeón, Valladolid, 2009, vol. I, pp. 407-422.

14 Beceiro Pita, I. y Córdoba de la Llave, R., Parentesco, poder y mentalidad. La nobleza castellana siglos XII-XV, Madrid, 1990, pp. 148-150. El siguiente miembro en continuar la línea nobiliaria fue Gómez Carrillo de Albornoz el Feo: fue señor de Ocentejo, y por herencia de su tía-abuela doña María de Albornoz, recibió los señoríos de Beteta, Torralba, Ribagorda y Albornoz, Mignot, C., ob. cit., p. 263. Así consta en un documento del archivo catedralicio, fechado el 4 de marzo de 1454 y recogido en la obra de SANZ Y DíAz, C., ob. cit., doc. 717 , p. 75.

15 Masnata y de Quesada, D. E., «La Casa Real de la Cerda. Precisiones, rectificaciones y ampliaciones», Estudios genealógicos y heráldicos, Madrid, Asociación Española de Estudios Genealógicos y Heráldicos, 1 (1985), p. 220 y GuTiÉrReZ Coronel, D., ob. cit., p. 44.

16 Enrique II dio autoridad a todas estas cláusulas en Soria, 22 junio 1378, R(eal) A(cademia) (de) (la) H(istoria), Salazar y Castro, M-9, fols. 306v-307v. 
Enrique II para vender las villas Alcocer, Salmerón y Valdeolivas, «en el Infantadgo, entre Taxo y Guadiela», a Gómez García de Albornoz ${ }^{17}$.

\section{Gómez García de Albornoz († 1380)}

Micer Gómez García de Albornoz fue el VI señor de Albornoz y mayordomo mayor de Enrique $\mathrm{II}^{18}$. Fue capitán de las tropas papales en Italia al mando de su tío el cardenal Gil de Albornoz. Adquirió por compra las villas de Alcocer, Salmerón y Valdeolivas en 1371. Falleció en Italia, donde fue señor de Ascoli y capitán general de los ejércitos de la reina Juana de Nápoles, y fue sepultado en el convento de Santa Clara de Alcocer.

Contrajo matrimonio con Constanza Manuel, también llamada Constanza de Villena, señora del Infantado (Alcocer), Carcelén y Montealegre, hija de Fernando Manuel, señor del Infantado y adelantado mayor de Murcia, y nieta del infante don Juan Manuel. Fueron padres de Juan de Albornoz, que continuó la línea sucesoria.

Tuvo un hijo ilegítimo, Garci Álvarez de Albornoz, que adquirió gran presencia política en Cuenca las dos primeras décadas del siglo Xv, al ocupar diversos cargos concejiles, entre ellos la alcaldía, la regiduría y la guarda mayor de la ciudad. De este personaje, que debió tener un oscuro ascenso por su condición ilegítima, no se dice nada en las genealogías y trabajos clásicos sobre el linaje Albornoz ${ }^{19}$. Garci Álvarez de Albornoz fue regidor de Cuenca en la última década del siglo XIV, como muestra un documento en el que aparece como testigo de una carta de poder concedida a Marcos Sánchez para representar al concejo en una determinación de términos con los lugares de señorío ${ }^{20}$. Estaba casado con Guiomar, a la que se ofrecieron unos oficios responsorios en la catedral de Cuenca en $1420^{21}$. De su posición preeminente dentro de la sociedad conquense de los albores del siglo XV dan muestra sus numerosos negocios económicos con el cabildo catedralicio de la ciudad, que analizaremos posteriormente.

\section{Juan de Albornoz († 1389)}

Otro de los miembros importantes del linaje fue Juan de Albornoz, que heredó sus títulos: VII señor de Albornoz, del Infantado, etc., y copero mayor del rey Juan I. Testó

17 Sevilla, 26 mayo 1374 [era de 1409], RAH, Salazar y Castro, M-9, fols. 307v-308r. El marqués de Villena, que había sido apresado durante la batalla de Nájera contra el Príncipe de Gales, fue representado por su hijo. Enrique II confirmó esta venta a Micer Gómez de Albornoz en Toro, 22 septiembre 1374 [era de 1409], RAH, Salazar y Castro, M-9, fols. 308v-309r. Ambos documentos están fechados por la era hispánica.

18 Soria, 22 junio 1378, RAH, Salazar y Castro, M-9, fols. 306v-307v.

19 Gutiérrez Coronel, D., señala que este hijo ilegítimo debió destinarse al estado eclesiástico porque en el testamento de su tío Alvar García de Albornoz le dejó «tres mil maravedís para libros», ob. cit., p. 47.

20 Cuenca, 17 julio 1390, AMC, leg. 47, exp. 3, fol. 52v. Como alcalde de Cuenca también aparece en condición de testigo en una carta de poder del concejo conquense a favor de varios vecinos para que acudan al amojonamiento entre Moya y su término, Cuenca, 3 agosto, 1398, AMC, leg. 51, exp. 2, publ. Colección..., ob. cit., doc. 163, pp. 378-379.

21 Cuenca, 3 enero 1421, Chacón Gómez-Monedero, F. A., Carrasco Lazareno, M. T. y Salamanca LóPez, M., Libros de Actas Capitulares de la Catedral de Cuenca. II (1418-1422), Cuenca, Seminario de Cultura Lope de Barrientos-Alfonsípolis, 2008, doc. 690, p. 256. El pago por los oficios ascendía a 100 mrs. y debía efectuarse antes de las Carnestolendas. 
en 1389, en Fuente el Maestre, y mandó que le enterrasen en la capilla familiar de la catedral de Cuenca y fundó cinco capellanías. Ordenó que sus mayorazgos los heredaran sus hijos y descendientes, anteponiendo la primogenitura y la línea masculina, y excluyendo a quien no tomase su apellido y armas. Incluso, en defecto de sucesión, sus posesiones pasarían a Garci Álvarez de Albornoz, su hermano no legítimo, y a sus hijos; y si éste no los tuviese, heredaría el mayorazgo Álvaro de Luna y sus descendientes ${ }^{22}$. A su madre Constanza de Villena le entregaba de por vida las villas de Alcocer, Valdeolivas y Salmerón, y las heredades de Jabalera, Millana y Burvanos, que deberían ser repartidas entre sus herederos.

Había contraído matrimonio con Constanza de Castilla, hija del infante Tello de Castilla — hijo de Alfonso XI-, señor de Aguilar, alférez mayor del rey, y de doña Leonor de Guzmán, señora del Infantado, Iniesta y sus aldeas, Requena y otros lugares. Ésta recibió en el testamento «todos los muebles de su casa, y, para su manutención, la renta de Torralba y de los lugares de Poyatos y Tragacete, y las casas de Ribagorda y Arrancacepas, mientras no se casare. Fueron padres de María de Albornoz y de Beatriz de Albornoz, de la que estaba encinta en el momento de formalizar su testamento Juan de Albornoz» ${ }^{23}$.

Tenemos constancia de que a la muerte de Juan de Albornoz, su mujer Constanza y sus hijas se hicieron cargo de todos sus señoríos, salvo de Beamud, que fue traspasado a Gonzalo Fernández de Albornoz ${ }^{24}$.

\section{La extinción del linaje: María de Albornoz († 1440) y Beatriz de Albornoz († ¿1440?)}

La extinción del linaje Albornoz se produjo en la década de los cuarenta del siglo XV, al quedar sin sucesión legítima la línea troncal. María de Albornoz fue la VIII señora de Albornoz, el Infantado, etc. que casó con Enrique de Villena el Nigromante, conde de Cangas y Tineo, maestre de Calatrava, hijo de Pedro de Aragón, con quien no tuvo sucesión. A su muerte, el patrimonio de la casa de Albornoz se dividió entre el Condestable Álvaro de Luna, el linaje Mendoza, señores de Cañete, y el linaje Carrillo. Concedió su patrimonio a su primo Álvaro de Luna «con tal condiçión que tome las armas e apellido de Albornoz, porque el dicho linaje de Albornoz no perezca ${ }^{25}$. Este documento pone de manifiesto la importancia de la conciencia de linaje asumida por los miembros de la nobleza conquense.

22 Sobre las pautas del procedimiento de sucesión puede consultarse OrTEGA CERVIGÓN, J. I., «Estrategias matrimoniales, propiedad y mayorazgo en los linajes conquenses del siglo XV», en Familia y organización social en Europa y América, siglos XV-XX. Sesión I, GómeZ CARRASCO, C. J. (ed.), Familias, recursos humanos y vida material (Murcia-Albacete, 8-10 diciembre 2007), en prensa.

23 Mártir Rizo, J. P., ob. cit., p. 253 y GutiérRez Coronel, D., ob. cit., p. 48. El rey Enrique II emitió una cédula para que se recibiera a Juan de Albornoz como señor de Moya en Vitoria, en 1377 [era de 1412], RAH, Colección Abella, leg. $1^{\circ}$, doc. 52.

24 Constanza de Castilla tuvo que afrontar los apeos de términos de Uña, Poyatos, Beteta y Tragacete en 1390, AMC, leg. 47, exp. 3, publ. Colección..., ob. cit., doc. 131, pp. 301-314.

25 Alcocer, 15 marzo 1432, RAH, Salazar y Castro, M-10, fol. 63r y también publicado por CALDERÓN Ortega, J. M., Álvaro de Luna (1419-1453). Colección diplomática, Madrid, 1999, doc. 36, p. 112. 
Beatriz de Albornoz, llamada la Ricahembra, fue la IX señora de Albornoz, del Infantado, de Utiel, Moya, Requena, Torralba, Beteta y seis villas del futuro marquesado de Cañete. Su padre le había dejado los lugares de Valdemeca y Uña y 10.000 florines para su enlace matrimonial, que tuvo lugar en 1403 con Diego Hurtado de Mendoza, señor de Cañete, montero mayor del rey y guarda mayor de Cuenca ${ }^{26}$; fueron padres de Luis Hurtado de Mendoza. Al fallecer éste sin sucesión de su matrimonio con Teresa de Toledo, la línea principal del linaje quedó extinguida, aunque parte de su patrimonio fue asumido por la familia Carrillo.

\subsection{La herencia del patrimonio de los Albornoz y su dispersión}

El linaje Albornoz fue de los primeros en implantarse en la tierra de Cuenca y durante el siglo XIV gozaron de gran importancia y preeminencia, por lo que habían acumulado un interesante patrimonio territorial en las tierras conquenses. Beatriz de Albornoz, casada con el señor de Cañete, recibió la herencia paterna de su mujer en 1403: Uña, Valdemeca y 10.000 florines. El resto del patrimonio de Juan de Albornoz y Constanza de Villena - Albornoz, Torralba, Utiel, Beteta, Moya, Ribagorda y las villas del Infantado (Alcocer, Salmerón, Valdeolivas y San Pedro Palmiches) - fue para la hija primogénita María, casada con Enrique de Villena. El hijo de Beatriz de Albornoz y Diego Hurtado, Luis Hurtado de Albornoz, heredó los lugares de Uña, Valdemeca, Carcelén, Montealegre, Poyatos, Tragacete, Cañada el Hoyo, Casa del Cardenal y los heredamientos de Valera de Suso, Valera de Yuso, Ballesteros y Moya. Al fallecer Luis sin descendencia en 1431, el patrimonio de los Albornoz lo heredó su padre Diego Hurtado de Mendoza, quien, viudo de Beatriz de Albornoz, había casado en segundas nupcias con Teresa de Guzmán ${ }^{27}$; ambos formaron el mayorazgo de la Casa de Cañete en 1442. Unos años antes, poco después de haber fallecido su hijo Luis, Diego Hurtado había dado en trueque a Fernando de Ribera, su escudero, los lugares de Carcelén y Montealegre por las aldeas de San Pedro de Palmiches y Puente de Guadiela:

Yo, Diego Furtado de Mendoça [...], otorgo y conozco que do en canvio y en nombre de canvio por juro de heredad, para sienpre jamás, a vos Ferrando de Ribera, vasallo del dicho señor Rey, vezino de la çibdad de Cuenca, los mis lugares Carcelén y Montealegre con el castillo y con todas las otras pertenencias, y montes y pastos y dehesas y aguas corrientes y estantes y manantiales, y con la justicia alta y baxa y juredicción civil y criminal y mero y misto inperio, y los quales dichos lugares vos do con todos sus términos y con todas sus entradas y salidas y serbidumbres reales y personales [...].

26 Ortega Cervigón, J. I., «La proyección política y señorial de los Hurtado de Mendoza en Cuenca y su tierra durante el siglo XV», II ${ }^{o S}$ y III ${ }^{\text {OS }}$ Premios de Investigación Juan Giménez de Aguilar, Cuenca, 2003, pp. 9-84.

27 A(rchivo) H(istórico) N(acional), NOBLEZA, Osuna, leg. 3329, cit. Franco Silva, A., «El destino del patrimonio de don Álvaro de Luna. Problemas y conflictos en la Castilla del siglo XV», Anuario de Estudios Medievales, 12 (1982), pp. 549-583, en concreto p. 555. Ver también Gutiérrez Coronel, D., ob. cit. pp. 50-51. 
A cambio recibió el lugar de San Pedro de Palmiches con sus montes y su puente y los «solares de molinos de la Ribera de Guadiela [...] con el puente que es en Guadiela [...] y con el diezmo de la madera que por el dicho río pasare». El valor de las villas que otorgaba Diego Hurtado era mayor (500 sueldos frente a 3.000 florines de oro), pero «por muchos servicios y honrras que de vos he resçebido y resçivo de cada día, vos lo do en pura y justa donación» ${ }^{28}$.

María de Albornoz había nombrado heredero de su patrimonio a su primo Álvaro de Luna en 1432, previa licencia de Juan II. Su padre Juan de Albornoz había ordenado en su testamento que, en tal caso, el patrimonio pasara a Gómez Carrillo de Albornoz o, en segundo término, a Álvaro de Luna, padre del Condestable de Castilla: María de Albornoz entregó a Juan de Salcedo el Mozo, en nombre del Condestable, «las villas de Albornoz e Veteta e Torre Alva e la casa de Ribagorda e la villa de Salmerón e de Alcoçer, con todos los heredamientos que yo he en tierra de Moya e de Utiel e de Requena» ${ }^{29}$. El patrimonio incluía la villa de Salmerón, perteneciente al Infantado y administrada en parte por Diego Hurtado de Mendoza en calidad de padre de Luis Hurtado de Albornoz ${ }^{30}$. El Condestable, echando mano de amenazas, logró la renuncia de Diego Hurtado a la mitad de Salmerón «por muchos favores que le debía al Condestable y los que esperaba recibir de él en el futuro» ${ }^{31}$.

28 La escritura de permuta se hizo en Olmeda de la Cuesta, 8 de noviembre de 1431, RAH, Salazar y Castro, M-9, fols. 303r-304r. Carcelén y Montealegre eran villas situadas en la órbita del señorío de Villena y pertenecían al obispado de Cartagena; en la actualidad son municipios de la provincia de Albacete.

29 Alcocer, 15 marzo 1432, RAH, Salazar y Castro, M-10, fols. 62r-64r, Franco Silva, A., ob. cit., pp. 555-556 y CALDERón ORTEGA, J. M., ob. cit., docs. 36 y 37, pp. 110-117. María de Albornoz cedió sus derechos - martiniega, portazgo, escribanía y almotacenía - sobre la villa de Alcocer a cambio de 30.000 mrs. anuales de moneda blanca, que dos blancas hacen un maravedí, 1 mayo 1433, Catastro de Ensenada 1752), Archivo de la Delegación de Hacienda de Guadalajara, fol. 58.

30 Diego Hurtado de Mendoza, Gómez Carrillo y Enrique de Villena tuvieron que renunciar a sus pretensiones sobre los bienes de los Albornoz, Mignot, C., ob. cit., p. 262.

31 Conoscida cosa sea a todos quantos la presente oyrán y verán como yo, Diego Furtado de Mendoza, montero maior de nuestro señor el Rey y del su Consejo, por quanto yo avía y he, y pretendía y pretendo aver acción y derecho a la meitad de la mi villa de Salmerón y a los vasallos de ella, por razón del señorío de la dicha villa, en los quales dichos vasallos yo he trabtado y trabto pleyto ante los oydores de la Abdiencia del dicho señor Rey, pidiendo a los dichos vasallos que me resciviesen a la posesión y señorío de la mentad de la dicha mi villa, la qual me pertenescía y pertenesce aver así por fin y herencia de Luis Furtado de Albornoz, mi fijo, al qual pertenesció aver por fin y herencia de doña Constanza de Villena, su visabuela, como en otra qualquier manera según que más largamente en el proceso del dicho pleito se contiene. La qual dicha villa vos, el señor don Álvaro de Luna, Condestable de Castilla y conde de Santesteban, posedes y tenedes por vuestra y como vuestra. Por ende, reconosciendo las grandes gracias, y mercedes, y ayudas, y buenas obras que yo he rescibido de vos, el dicho señor Condestable, $y$ entiendo rescevir en adelante, y el cargo que de vos tengo, de mi propia y agradable voluntad, sin premia, y sin fuerza, y sin miedo, y sin engaño alguno, y sin otro ynduçimiento nin costrenimiento, otorgo y conozco que fago cesión, y alsamiento, y traspasación en vos y a vos, el dicho señor Condestable, de todo el derecho y acción, o demanda, o petición, o buena rasón que a mí, el dicho Diego Furtado, pertenezca o pertenescer pueda contra las dichas meytad de la dicha mi villa y vasallos della, así por subcesión, y fin, y herencia del dicho Luis Furtado, mi fijo, como en otra qualquiera manera, y por qualquier razón que sea, de qualquier efecto, qualidat, misterio que sea o ser pueda, callada o expresamente, en qualquier manera que me competa o competer pueda, para que lo ayades todo ello por vuestro y como buestro para sienpre jamás, ca yo renuncio el dicho pleyto y la acción que yo he contra la meytad de la dicha mi villa y castillo y vasallos de ella, y me parto y quito dél, y lo reuoco, y anulo y do por ninguno caso y de ningún valor con propósito y intención de lo non proseguir de aquí adelante en 
La ambición del Condestable era heredar todo el patrimonio de los Albornoz y así consiguió que María de Albornoz le cediese todos sus derechos a Moya y Utiel en 1437. En virtud de esta donación puso pleito a Diego Hurtado de Mendoza por la villa de Valdeolivas y otros pueblos y heredades que habían pertenecido a Beatriz de Albornoz, basándose en que él era legítimo heredero del linaje y Diego Hurtado carecía de derecho para ello, pues no pertenecía al linaje. Álvaro de Luna también puso a María de Albornoz en contra de su cuñado por los bienes de su hermana; los tres firmaron un compromiso para evitarse pleitos con motivo del derecho que cada uno pretendía tener en la villa de Valdeolivas ${ }^{32}$.

Diego Hurtado se vio obligado a comprometer sus diferencias con Álvaro de Luna en la sentencia dada en Valladolid en julio de 1437. Ésta dictaminó que Diego Hurtado debía ceder a Álvaro de Luna, en los diez primeros días siguientes, la villa de Valdeolivas, el lugar de San Pedro de Palmiches con su puente y la heredad de Millana, con cuantas casas, viñas y bienes raíces poseía en ellas, así como los bueyes y aparejos de labranza de las mismas. El Condestable recibió además la aldea de Tragacete con cuantos bienes raíces «aboyados e aparejados» poseía María de Albornoz en ella, salvo los 1.000 mrs. que esta señora tenía dados de renta anual al cabildo de la catedral de Cuenca en la dehesa del Poyal. Los jueces determinaron que los lugares de Poyatos, Uña y Valdemeca con sus dehesas quedasen para Diego Hurtado ${ }^{33}$.

juicio nin fuera dél, constituyendo a vos, el dicho señor Condestable, en la mesma acción y en el señorío de todo ello [...]; y fago gracia y donación pura y propia y simple, y non reuocables que es dicho entre vibos, sin alguna condición nin contradición, dela dicha mi meytad dela dicha mi villa, con el castillo y fortaleza della, y con sus vasallos, y con el mero y misto imperio, y con la juridiçión y justicia ceuil y criminal alta y baja, y con todo su término y destrito, y con todas sus entradas y salidas, y con todos sus prados, y montes, y pastos, y aguas corrientes, estantes y manantes, y con todos sus derechos directos y útiles, y otros qualesquier que les pertenezca o pertenescer pueda en qualquier manera y por qualquier razón, desde la fosa del monte hasta la piedra del río y desde la piedra del río fasta la fosa del monte [...]; e levanto qualquier pleyto homenaje hecho a Luis Furtado, o a él o a su nombre [...]. En presencia de Martín Días y Furtán González, alcalde de la mi villa de Valdeolivas.

Escritura otorgada en Valdeolivas, 7 agosto 1432, AHN, NOBLEZA, Osuna, leg. 1724, nº 161-2, cit. FRANCo Silva, A., ob. cit., p. 556. Existe una copia de este documento en la RAH, Salazar y Castro, 7 agosto 1432 , M-25, fols. 206r-207v.

32 Sepan quantos esta carta de compromiso vieren cómo yo, Diego Hurtado de Mendoza, montero mayor de nuestro señor el Rey, por my, e yo, el bachiller Iohan Sánches de Moya, por virtud de vn poder que yo he e tengo de doña María de Albornos en nonbre della, e yo, Alfonso Gonçáles de Toro, escribano del dicho señor Rey, por virtud de vn poder que yo he e tengo de don Álvaro de Luna, condestable de Castilla, en su nonbre, los tenores de los quales son estos que se siguen. Sepan quantos esta carta de poder vieren cómo por quanto entre doña María de Albornos de la vna parte e de la otra Diego Hurtado de Mendoza, montero mayor del Rey nuestro señor, son pleitos e contiendas sobre rasón de çiertas villas, e logares, e vasallos e otras cosas que la dicha doña María demanda al dicho Diego Hurtado, e el dicho Diego Hurtado a la dicha doña María.

Valladolid, 7 junio 1437, AHN, NOBLEZA, Osuna, leg. 1724, nº. 14. Álvaro de Luna y María de Albornoz fueron representados por sus respectivos apoderados en la firma de esta carta de compromiso.

33 AHN, NOBLEZA, Osuna, leg. 1724, nº 14 y leg. 1729, cit. Franco Silva, A., ob. cit., p. 557. Ya en 1428 consta ya la posesión por Diego Hurtado de Mendoza de Uña y Poyatos, aldeas insertas en el señorío de los Albornoz, AMC, leg. 187, exp. 2, fols. 16v-17r y leg. 189, exp. 7, fols. 32v-33r, cit. SÁNCHEZ BENITO, J. M. ${ }^{\mathrm{a}}$ y Guerrero Navarrete, Y., Cuenca en la Baja Edad Media: un sistema de poder urbano, Cuenca, Diputación Provincial, 1994, nota 201, p. 71. Tragacete está incluida en el mayorazgo de 1442, pero no podemos confirmar en qué momento exacto quedó incorporada al dominio de Diego Hurtado de Mendoza, aunque debió ser a partir de 1440, fecha del fallecimiento de María de Albornoz. 
En 1439 María de Albornoz, que murió sin descendencia un año después, añadió ciertas cláusulas a la donación de su cláusula al Condestable, que también disfrutó la posesión de una casa en Albornoz, las villas de Salmerón, Alcocer y Beteta, una casa y un heredamiento en Ribagorda y diversos derechos en Moya y Utiel ${ }^{34}$.

\section{LA REPRESENTACIÓN SIMBÓLICA DEL LINAJE}

Para alcanzar una visión global de los linajes castellanos en la baja Edad Media, hemos de atender al análisis de distintos aspectos de su caracterización simbólica: el apellido y las armas heráldicas, los signos externos como el solar o las viviendas donde habitaban, o el propio conjunto de servidores del que disponían. Estos elementos posibilitaban la cimentación de las estructuras de parentesco que organizaban los linajes de forma cohesionada, aunque rígida y jerarquizada. También les permitía «legitimar y publicitar su posición de preeminencia en el conjunto social» ${ }^{35}$.

Durante las centurias bajomedievales se asistió a la generalización del «topolinaje», que identificaba el apellido con la procedencia de los antepasados ${ }^{36}$. Así, la nobleza asentada en el obispado de Cuenca utilizaba como apellido el toponímico de origen, ya sea en suelo propiamente conquense (Albornoz, Alarcón) o el de sus lugares de procedencia, castellano (Mendoza, Sandoval) o portugués (Acuña). Otros apellidos se vinculan a orígenes legendarios con connotaciones etimológicas, como sucedía con los Carrillo.

La conciencia de linaje se demuestra en el deseo de permanencia del apellido, aun cuando la línea principal estaba condenada a la extinción, como pretendía María de Albornoz al donar sus bienes a su primo, el condestable Álvaro de Luna

E por quanto don Juan, su fijo primero legítimo del dicho señor Condestable ha de heredar el mayorazgo del dicho señor Condestable e tomar las armas de Luna, por ende por la presente mando e quiero e es mi voluntad que después de los días del dicho señor Condestable, agora fallesçiendo el dicho señor Condestable antes que yo o después de mí, que aya la dicha mi Casa de Albornoz e logar con todas las villas e logares e castillos e fortalezas susodichas e declarados el su fijo segundo legítimo quél oviese en la condesa mi prima, su muger legítima, con tal condiçión que en mi vida no pueda entrar ni tomar cosa alguna de lo sobredicho nin poner justiçias nin alcaydes en las dichas villas e castillos e fortalezas que yo poseo nin tomar los derechos dellas en mi

34 Torralba, 6 marzo 1439, RAH, Salazar y Castro, M-10, fols. 59r-60r y publ. Calderón OrTEGA, J. M., ob. cit., doc. 56, pp. 183-185.

35 Quintanilla Raso, M. ${ }^{a}$ C., «Los grandes nobles», en Ladero Quesada, M. Á. (coord.), El mundo social de Isabel la Católica. Medievalismo, 13-14 (2004), p. 135.

36 Quintanilla Raso, M. ${ }^{a}$ C., «La renovación nobiliaria en la Castilla bajomedieval. Entre el debate y la propuesta», La nobleza peninsular en la Edad Media, La Nobleza peninsular en la Edad Media. VI Congreso de Estudios Medievales, León, Fundación Sánchez-Albornoz, 1999, p. 283. Se pueden ver algunos ejemplos concretos para otros linajes castellanos en las obras de, entre otras, GERBET, M.-C., La nobleza en la Corona de Castilla. Sus estructuras sociales en Extremadura (1454-1516), Cáceres, 1989 y Quintanilla Raso, M. ${ }^{a}$ C., Nobleza y señoríos en el reino de Córdoba. La casa de Aguilar (s. XIV-XV), Córdoba, 1979. 
vida, e que tome el apellido e armas de Albornoz. E si se entremetiere de tomar cosa alguna de lo susodicho e posiere justiçia o alcaydes en las dichas villas e fortalezas que yo poseo o en alguna dellas en mi vida, que por ese mesmo fecho pierda la dicha herençia e el contrabto sea ninguno e así mesmo la pierda si non tomare las armas e apellido de Albornoz o mezclara otro apellido o armas con ello ${ }^{37}$.

Las armas de los Albornoz son una banda verde en campo amarillo, insignias que refieren las historias antiguas que llevaba Pompeyo el Grande ${ }^{38}$, cónsul romano que vivió en el siglo I a. C.

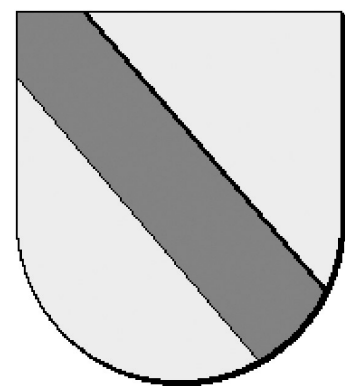

Armas de los Albornoz.

El solar era la casa o lugar de residencia de la región donde se había implantado cada linaje. El lugar de Albornoz, «pueblo principal junto al Villarejo, adonde es ahora San Gil, o San Blas de Albornoz» ${ }^{39}$, era el núcleo principal de residencia del linaje albornociano. En la actualidad no existen vestigios arqueológicos del lugar donde estuvo la villa de Albornoz. En los siglos XIII y XIV Albornoz se documenta como una aldea de tierra de Alarcón, situada en las cercanías de Villarejo de Fuentes, en el término actual de Villamayor de Santiago, a poca distancia del fuerte de Dañador o Añador que en 1178 poseía Pelayo Fernández, que posteriormente entregó a la orden de Santiago.

En Cuenca el palacio de los Albornoz estaba situado al norte de la catedral, junto a la hoz del Huécar, en el barrio de San Pedro, collación donde también habitaban otras familias nobiliarias y poderosas. Cerca del palacio fortificado, a comienzos del siglo XV, García Álvarez de Albornoz «tomaba a censo un solar de la ciudad con idea de hacer huerta». El comendador Fernán Gómez de Albornoz había poseído amplios edificios en

37 Torralba, 6 marzo 1439, publ. CALDERÓn OrtegA, J. M., ob. cit., doc. 56, pp. 183-185.

38 MÁrtir Rizo, J. P., ob. cit., p. 252.

39 Así lo localiza Mártir Rizo, J. P. en el siglo xvıl, ibidem, p. 252 y RodríGuez Llopis, M., «Procesos de movilidad social en la nobleza conquense: la tierra de Alarcón en la Baja Edad Media», García GonZÁlez, F. (ed.), Tierra y familia en la España meridional, siglos XIII-XIX. Formas de organización doméstica y reproducción social, Universidad de Murcia, 1998, p. 50. 
la parte alta de la collación de San Martín, cercanos al palacio episcopal y al postigo de Santa María ${ }^{40}$.

Los criados eran servidores domésticos que andaban «continuamente» con el señor, de procedencia social humilde y con unas funciones principalmente domésticas y militares, sobre todo escuderos y acostados; también podían realizar tareas administrativas - si eran letrados o secretarios bien preparados - y gubernativas en las villas. Recibían un numerario, aparte de los vestidos y los alimentos. Los criados tenían estrechos lazos personales y afectivos con los señores, ya que debían mostrar un alto grado de confianza y fidelidad; así lograban una protección completa del señor, que a veces lograba su exención de pechos y tributos, la concesión de mercedes regias o cargos en los gobiernos locales o algunas dotaciones económicas. El grupo de los criados era una prolongación de la familia, muchos de ellos realizaron su crianza en los propios señoríos, aunque tenían una consideración menor respecto a los hijos y los parientes colaterales directos ${ }^{41}$. Los nobles han utilizado con frecuencia los lazos clientelares, tanto en su vida cotidiana como para servir sus ambiciones políticas. Algunos especialistas han establecido una clasificación en la relación entre el señor y sus distintos tipos de subordinados: los criados generan un vínculo estructural, mientras que los allegados mantienen una ligazón coyuntural ${ }^{42}$.

La documentación muestra a los criados del linaje Albornoz en la realización de diversas tareas de confianza. Los escuderos, que sabían servir un caballo con sus armas, no sólo tenían ocupaciones militares. Conocemos el nombre de Alfonso de Monferrat, escudero de García Álvarez de Albornoz ${ }^{43}$. Los procuradores se encargaban de realizar las operaciones de compraventa o acudir a los procesos judiciales que correspondían a sus titulares, a quienes representaban con total garantía. Los procuradores representaban a los señores en pleitos y demandas ante cualquier señor, alcalde, juez ordinario o delegado. Entre sus cometidos estaban la potestad para demandar, defender, responder, negar, conocer, proponer, exhibir, alegar, requerir, protestar y replicar las posibles acusaciones contra la persona o intereses de su señor. Pascual Sánchez, criado de Fernán Gómez de Albornoz, pidió a

40 SÁnchez Benito, J. M. , El espacio urbano de Cuenca en el siglo XV, Cuenca, Diputación Provincial, 1997, pp. 20, 21 y 24 e IBÁÑEZ MARTíNEZ, P. M., Arquitectura y poder: espacios emblemáticos del linaje Albornoz en la ciudad de Cuenca, Cuenca, Universidad de Castilla-La Mancha, 2003.

41 Beceiro Pita, I. y Córdoba de la Llave, R., ob. cit., pp. 123-146 y 331-337. En varios testamentos nobiliarios se agradecían servicios a los criados, se hablaba de su cariño, se les beneficiaba con legados y se les encargaba el cuidado de la mujer, los hijos y la hacienda, CARLÉ, M. ${ }^{a}$ C., «La sociedad castellana en el siglo XV: los criados», Cuadernos de Historia de España, LXIX (1987), p. 110. Una visión de conjunto en el trabajo de BeCEIRo PITA, I., «Criados, oficiales y clientelas señoriales en Castilla (siglos XI-XV)», Cuadernos de Historia de España, LXXV (1998-1999), pp. 59-84 y, para el ámbito conquense, OrTEGA CERVIGÓN, J. I., «Por seruiçios muchos e buenos que me ha fecho. Los criados de las casas nobiliarias conquenses», Anuario de Estudios Medievales, 39/2 (2009), pp. 703-721.

42 Gerbet, M.-C., «Nobles et clients dans le Royaume de Castille: criados et allegados en Estrémadure dans des années 1500», Castellano Castellano, J. L. y Sánchez-Montes González, F. (coords.), Carlos V. Europeísmo y universalidad. Vol. IV. Población, economía y sociedad (Granada, mayo de 2000), Madrid, Sociedad Estatal para la Conmemoración de los Centenarios de Felipe II y Carlos V, 2001, pp. 337-345. La solidaridad política y judicial, la protección del uno y la fidelidad del otro que se manifiesta por unos gestos de deferencia, son rasgos de raigambre feudo-vasallática que también presentes en el siglo Xv.

43 Cuenca, 17 enero 1421, Chacón Gómez-Monedero, F. A., Carrasco Lazareno, M. T. y SalamanCA LóPEZ, M., ob. cit., doc. 693, p. 257. 
Alfonso XI la confirmación de una carta de Fernando IV en la que eximía del pago de portazgo a los vecinos de Cuenca salvo en Toledo, Sevilla y Murcia ${ }^{44}$. Pedro González de Cuenca, criado de García Álvarez de Albornoz, aparece en distintos cometidos relacionados con la entrega de determinados pagos: 300 mrs. a Alfonso Martínez de Valverde; el importe de 24 reses del refitor y el préstamo de Solera del año de 1419, que había recibido de Alfonso González de Cañizares; la obligación para satisfacer a Benito Fernández, racionero de la catedral, «5 florines de oro en virtud del mantón verde, forrado en veros, propiedad de la que fuera mujer de García Álvarez de Albornoz»; o el pago a Pedro López Serrano, pitancero del cabildo catedralicio, de $100 \mathrm{mrs}$. por los oficios realizados por el ánima de doña Guiomar, mujer de Garci Álvarez de Albornoz ${ }^{45}$.

Otros criados aparecían como testigos, como en la donación del patrimonio de María Albornoz a su primo Álvaro de Luna en la que figuraban su capellán Juan Martínez de Salmerón y su mayordomo en Torralba, Juan Martínez de Castillejo ${ }^{46}$, o traspasos económicos: el citado Pedro González aparecía como testigo de la entrega en prendas de una morada situada en el Alcázar ${ }^{47}$. Los nobles, en contraprestación, intentaban favorecer a sus criados y algunos de ellos gozaban de vivienda propia, como demuestra la vecindad en la iglesia de san Nicolás de Rodrigo, hijo de Ruy González, criado de Garci Álvarez de Albornoz $^{48}$.

\section{LAS RELACIONES DE PODER DEL LINAJE ALBORNOZ}

\subsection{Protagonismo en la política del reino castellano}

Las relaciones de poder Monarquía-Nobleza han sido una constante historiográfica en el estudio de la evolución política del reino castellano en la Baja Edad Media. Los Albornoz mantuvieron una actitud de colaboración permanente con la monarquía, recompensada con títulos honoríficos para desempeñar cargos y oficios cortesanos de relevancia políticoadministrativa en compensación por los servicios militares prestados - participación en los conflictos civiles - y con mercedes - como la tenencia de determinados señoríos - , dentro de los parámetros generales en los que se desenvolvió la nobleza castellana. Durante el reinado de Alfonso XI, en el que algunos miembros del linaje Albornoz participaron en batallas frente a los musulmanes y fueron armados caballeros en Burgos en 1331. Su parentesco con los Luna les facilitó también la ayuda de los monarcas aragoneses ${ }^{49}$.

44 Cuenca, 20 abril 1346, AMC, leg. 2, exp. 19, publ. Colección..., ob. cit., doc. 66, pp. 184-185.

45 Cuenca, 8 abril y 24 agosto 1419, 9 noviembre 1420 y 3 enero 1421, ChaCón GómeZ-Monedero, F. A., Carrasco Lazareno, M. T. y Salamanca LóPez, M., ob. cit., docs. 236, 352, 661 y 690, pp. 106, 142, 244 y 256.

46 Torralba, 6 marzo 1439, publ. CALderón Ortega, J. M., ob. cit., doc. 56, p. 185.

47 Cuenca, 12 octubre 1418, Chacón Gómez-Monedero, F. A., Carrasco Lazareno, M. T. y SalaMANCA LÓPEZ, M., ob. cit., doc. 106, p. 65.

48 Cuenca, 8 abril 1419, ibidem, doc. 91, p. 60.

49 Gerbet, M.-C., Las noblezas españolas en la Edad Media. Siglos XI-XV, Madrid, Alianza Editorial, 1997, pp. 170-171. 
Álvar García de Albornoz tuvo un especial protagonismo político en los años centrales del siglo XIV, durante el enfrentamiento entre Pedro I el Cruel, a quien servía, y Enrique II de Trastámara, hermanastro del monarca. En 1353 Álvar García de Albornoz, junto al obispo de Burgos, don Juan de las Roelas, acudió como mensajero al rey de Francia «a le demandar que le diese por mujer a doña Blanca, su sobrina, fija del duque de Borbón». Ambos mensajeros vinieron a Valladolid el 25 de febrero con la futura reina, el vizconde de Narbona y otros caballeros franceses, pese a que el monarca Pedro I quería casarse con María de Padilla. Álvar García de Albornoz, que era copero mayor de la reina doña Blanca, fue como mensajero junto a Sancho Sánchez de Rojas, su ballestero mayor, al conde don Enrique «con los quales le envió mandar que se viniese luego a la su merced, e que le diese caballeros en arrehenes fasta que le entregase las fortalezas que tenía en Asturias, e las que tenía don Tello su hermano», prometiéndoles a ambos muchas mercedes y aconsejándoles que así lo hicieran ${ }^{50}$.

Álvar García de Albornoz se acercó al bando del conde Enrique y en 1354 se fue al lugar de Montealegre, que era de Juan Alfonso de Alburquerque, que estaba alzado. Un año después el rey Pedro fue a Cuenca a tratar pleitesía con Álvar García de Albornoz, «e don Ferrand Gómez su hermano, e otros sus parientes, los quales eran en esta demanda de la reyna doña Blanca», que la tenía presa. Álvar García de Albornoz tenía en Cuenca a don Sancho, hermano del rey e hijo del rey Alfonso XI y doña Leonor de Guzmán, para criarle. El rey estuvo en la aldea de Jábaga unos quince días y como no podía cobrar la ciudad por fuerza, alcanzó el acuerdo con ellos de que se mantuviera sosegada. Una vez derrotados los caballeros que estaban con la reina María, madre del rey, Álvar García de Albornoz y su hermano Ferrand Gómez, se llevaron a Sancho para el reino de Aragón, «ca non osaron quedarse en Castilla» ${ }^{51}$, pese al perdón regio para los habitantes de Cuenca y especialmente a los Albornoz Alvar García de Albornoz seguía exiliado en Aragón en 1356 y dos años más tarde sus bienes y los de su hermano Fernán se encontraban expropiados, y se intentaban vender al cabildo catedralicio ${ }^{52}$.

Unos años después, el rey aragonés Pedro IV envió como mensajeros al conde don Enrique, que estaba en Francia, a Álvar García de Albornoz y su hermano Fernán Gómez, «que eran dos caballeros naturales de Castilla, que estaban en Aragón por miedo del rey don Pedro de Castilla». En el camino hacia París encontraron otros caballeros castellanos - Gonzalo Mejía, comendador mayor de Castilla de la Orden de Santiago y Gómez Carrillo, que estaba a sueldo del rey de Francia en Languedoc-, quienes prometieron unirse al conde don Enrique y venirse para Aragón. El rey castellano Pedro I fue a Aragón

50 López de Ayala, P., «Crónica de don Pedro Primero», Crónicas, ed. cit., año 1353, caps. III y IX, pp. 65 y 72 .

51 Ibidem, año 1354, cap. XXIII, p. 114; año 1355, cap. XI, p. 150 y año 1356, cap. II, p. 166. La trayectoria política del rey castellano, el apartamiento de la reina doña Blanca y el «exilio encubierto» del cardenal Gil de Albornoz, fueron los motivos del alzamiento de los Albornoz, Moxó, S. de, «Los Albornoz. La elevación de un linaje...», ob. cit., p. 37.

52 SÁnchez Benito, J. M. ${ }^{a}$, Las tierras de Cuenca y Huete en el siglo XIV. Historia económica, ob. cit., pp. 68-69. Para apreciar el significado del perdón regio durante la etapa Trastámara, consultar el trabajo de NiETo Soria, J. M., «Los perdones reales en la confrontación política de la Castilla Trastámara», En la España Medieval, 25 (2002), pp. 213-266. 
desde Murcia y ganó varios castillos en tierra castellana pero levantados contra él, Miñón y Arcos, que eran de Fernán Gómez de Albornoz ${ }^{53}$.

Los miembros del linaje Albornoz participaron en distintos episodios bélicos de la época. En la batalla de Nájera, que tuvo lugar en el contexto de la Guerra de los Cien Años entre franceses e ingleses, en 1367, Álvar García de Albornoz combatió junto a Enrique de Trastámara, «de los de a caballo» y fue capturado preso. La batalla se saldó con el triunfo del pretendiente al trono Enrique, quien contó con la ayuda de Aragón y Francia. Álvar García de Albornoz, ya mayordomo mayor de Enrique II, junto a Pedro González de Mendoza, mayordomo mayor del infante don Juan, llegaron a la Mancha de Montearagón y combatieron en Requena contra compañas de Valencia, protegiendo la villa, que estaban por el rey de Castilla, frente a los del castillo, que estaban por el rey de Aragón ${ }^{54}$. Enrique II dotó de ciertas mercedes y privilegios tanto a las ciudades que le habían apoyado como a determinados caballeros y nobles. Alvar García de Albornoz «recibió cien excusados en 1370 , además de la renovación de dádivas anteriores» ${ }^{55}$.

La intervención de Juan I de Castilla en la crisis dinástica portuguesa, aliándose con parte de su alta nobleza, fue repelida militarmente por tropas de Portugal e Inglaterra. Álvar García de Albornoz el Joven, copero mayor de Juan I, fue uno de los capitanes que llegaron a Ciudad Rodrigo y entraron en Portugal por la tierra de Viseo y Cellorico. En la pelea de Troncoso, que tuvo lugar en 1385, lucharon contra el maestre Davis, rey de Portugal - Martín Vázquez de Acuña fue uno de sus capitanes - y «Álvar García escapó ferido» ${ }^{56}$. Este episodio bélico, tras la derrota militar de los castellanos en Aljubarrota, tuvo importantes consecuencias para el estamento nobiliario con la progresiva implantación en Castilla de los linajes portugueses emigrados que apoyaron al monarca castellano. En el obispado de Cuenca obtuvieron patrimonios territoriales los Acuña, los Pacheco y los Coello.

Los oficios cortesanos otorgaban gran prestigio político a los grupos nobiliarios que los desempeñaban. Los Albornoz disfrutaron los cargos de mayordomo mayor, como Álvar García de Albornoz, en época de Enrique II, y copero mayor, Álvar García de Albornoz lo hizo durante el reinado de Pedro I y su hijo Álvar García el Mozo y su nieto Juan de Albornoz lo fueron bajo Juan $\mathrm{I}^{57}$.

53 López de Ayala, P., «Crónica de don Pedro Primero», Crónicas, ed. cit., año 1357, cap. I, pp. 176-177 y año 1358, cap. XI, p. 199. Años después el monarca Pedro I pasó desde Monviedro a Cañete, año 1364, cap. V.

54 Ibidem, año 1367, caps. IV y XII, pp. 343 y 354 y LóPEZ DE AYALA, P., «Crónica del rey don Enrique, segundo de Castilla», Crónicas, ed. cit., año 1369, cap. II, p. 437.

55 SÁnchez Benito, J. M. ', Las tierras de Cuenca y Huete en el siglo XIV. Historia económica, ob. cit., p. 71.

56 López de Ayala, P., «Crónica de don Juan Primero», Crónicas, ed. cit., año 1385, cap. VIII, p. 587.

57 Para un contexto más amplio, puede consultarse nuestro trabajo, «Prestigio político y oficios reales: la nobleza conquense bajomedieval en el entorno cortesano», El estamento nobiliario. Poder político y económico. Anuario de Estudios Medievales, 37/2 (2007), pp. 563-595. En su origen, el mayordomo mayor era el primer oficial al frente de la Casa del rey y estaba encargado de dirigir los servicios palatinos y la administración de la Hacienda regia. La evolución administrativa bajomedieval creó otras categorías que fueron cumpliendo las funciones del mayordomo mayor - tesorero, despensero, camarero, copero, etc. - , aunque su dignidad siempre recayó en miembros de la alta nobleza castellana. En el reinado de Alfonso X aparece la primera mención del oficio de copero mayor, con la función de ser el máximo responsable de la mesa del rey, encargándose además de la copa, de la botillería y de la bebida. La quitación anual del oficio ascendía a 8.000 mrs. 


\subsection{Relaciones con el concejo de Cuenca}

En la esfera del gobierno concejil de Cuenca, los nobles participaban de forma directa especialmente desde el cargo de guarda mayor, o indirecta, mediante la designación de procuradores a las reuniones de Cortes y la influencia en el regimiento a través de sus clientelas $^{58}$.

El linaje Albornoz desempeñó el cargo de guarda mayor de Cuenca y su tierra, una figura institucional específica del ámbito conquense durante el siglo xv, realzada por el carácter fronterizo de Cuenca, tanto geográfico como territorial. El guarda mayor suponía el ejercicio de un cargo concejil - competencias en materia judicial, económica y fiscaly, como su nombramiento era regio, le servía a la Corona para pagar determinados favores y asegurarse necesarias lealtades, por lo que fue ostentado por miembros de la nobleza local ${ }^{59}$. A comienzos del siglo XV el cargo de guarda mayor de Cuenca era desempeñado por García Álvarez de Albornoz. En la documentación municipal consta este personaje como guarda mayor de la ciudad, al menos, entre 1411 y 1417. A partir de 1419 el oficio fue patrimonializado por los Hurtado de Mendoza, quienes utilizaron en ocasiones el sistema de lugartenencia en lugar de ejercerlo directamente. La principal función del guarda mayor era «veer e librar todos los negoçios de Cuenca y su tierra, junto a otros cavalleros e escuderos e omnes buenos çibdadanos, con quienes se reunía dos días en cada semana en las casas de los ayuntamientos desta çibdat» ${ }^{60}$. Entre sus atribuciones políticas estaba su presencia con voz y voto en el ayuntamiento, así como la de su lugarteniente.

El guarda mayor acudía como procurador de la ciudad de Cuenca a determinados eventos de relevancia política para el reino castellano, al estar considerado por el concejo como su máximo representante. En 1412 García Álvarez de Albornoz acudió a Guadalajara para estar presente en el acuerdo de paz que se iba a firmar entre Juan II —avalado por sus tutores - y el rey de Portugal: «Garçía Álvarez de Alvornoz, guarda mayor de la çibdat, vuestro procurador, vino a la dicha villa de Guadalfajara e se presentó ante los sobredichos del mi consejo con vuestra procuraçión para fazer el dicho juramento en diez e seys días de setienbre». Ante la no presencia del rey portugués, que «fasta agora non es venido nin se espera en breve su venida», se concedió licencia a los procuradores para volver a sus ciudades y no acrecentar así los gastos de la estancia, que debía costear cada concejo:

58 Sobre esta temática, centrada en el siglo XV, se puede consultar QuinTANILla Raso, M. ${ }^{\text {a C., }}$ «Política ciudadana y jerarquización del poder. Bandos y parcialidades en Cuenca», En la España Medieval, 20 (1997), pp. 219-250 y Ortega Cervigón, J. I., «Lazos clientelares y bandos nobiliarios conquenses durante el siglo XV», Espacio, Tiempo y Forma. Serie III. Historia Medieval, 19 (2006), pp. 211-231.

59 Algunos datos sistematizados sobre la naturaleza y características de este oficio concejil en el trabajo de Ortega Cervigón, J. I., «El intrusismo nobiliario en los concejos castellanos: el oficio de guarda mayor de Cuenca durante el siglo XV», en JiméneZ, J. F., EiroA, J. y OrTuÑo, J. (eds.), Actas I Simposio de Jóvenes Medievalistas. Lorca 2002, Murcia, 2003, pp. 147-162.

60 Cuenca, 7 septiembre 1411, A(rchivo) H(istórico) P(rovincial de) C(uenca), Pergaminos, $\mathrm{n}^{\circ} 130 ; 31$ octubre 1412, AMC, leg. 834, exp. 6, publ. Colección..., ob. cit., doc. 195, pp. 452-453; AMC, leg. 185, exp. 1, publ. Chacón Gómez-Monedero A. y Martínez Escribano, P. (dir. Jiménez Monteserín, M.), Actas municipales del ayuntamiento de Cuenca (Años 1417, 1419 y 1420), Cuenca, 1994, pp. 11-35 y Cuenca, 14 noviembre 1419, AMC, leg. 185, exp. 4, fol. 29r, publ. ibidem., p. 49. 
E [...] vos mando que dedes e paguedes al dicho Garçi Álvarez, vuestro procurador que acá enbiastes, su salario de la dicha procuraçión [...] acostunbrado de lo dar e pagar a los otros procuradores [en cada día [...] tres maravedís] [...] del día sobredicho que él aquí se presento con la dicha procuraçión fasta tres días después de la data desta mi carta que le yo di la dicha liçençia ${ }^{61}$.

Durante los enfrentamientos banderizos acaecidos en al ciudad de Cuenca en la segunda década del siglo Xv, el guarda mayor intervino para apaciguar a los nobles Diego Hurtado de Mendoza y Lope Vázquez de Acuña. Aprovechando la presencia de Enrique de Aragón, marqués de Villena, le habían ido a avisar a su villa de Torralba el 19 de octubre de 1417. El ayuntamiento reunido unos días después, presidido por García Álvarez de Albornoz, expuso que «ha muchos días que está aquí el noble señor don Enrique, el cual vino aquí por ruego de ellos para sosegar y poner buen sosiego en los alborotos», y había ordenado cosas que cumplían el servicio y provecho del rey, así como el del común, por lo que expresó su deseo de retornar a Torralba. Después de haber hecho «pesquisa e inquisiçión» don Enrique, tío del rey que pasó por Cuenca, García Álvarez de Albornoz, guarda mayor, y los alcaldes ordinarios de la ciudad, ésta envió «sus enbaxadores a los honrados Diego Furtado de Mendoça e a Lope Vazquez de Cunna a tractar e fablar con ellos algunas cosas que cunplian a serviçio de nuestro sennor el Rey e al poblamiento e bien e paz e sosiego de la dicha çibdat» ${ }^{62}$.

En ocasiones, el guarda mayor utilizaba también su cargo para su beneficio personal. Así, Garci Álvarez de Albornoz logró la donación de un molino en la hoz del Júcar y una serrería hidráulica, como muestra del régimen oligárquico conquense ${ }^{63}$. Incluso, la nobleza podía desempeñar otros oficios concejiles, como el propio Garci Álvarez de Albornoz, que aparece como caballero de la sierra en $1421^{64}$.

También es destacable el protagonismo que algunos miembros de la nobleza urbana y territorial adquirieron en las reuniones de Cortes castellanas, a las que acudieron como procuradores urbanos, en razón de su privilegiada posición política en la ciudad de Cuenca, no como representantes del brazo nobiliario. La procuración a Cortes originó disputas y conflictos entre los miembros de la oligarquía local; la vaguedad normativa por la que cada concejo elegía libremente a sus procuradores era violada en la práctica, con la inter-

61 Guadalajara, 31 octubre 1412, AMC, leg. 834, exp. 6, publ. Colección..., ob. cit., doc. 195, pp. 452453.

62 Cuenca, 19 octubre y 2 noviembre 1417, MuÑoz y Soliva, T., Noticias de todos los ilustrísimos señores obispos que han regido la diócesis de Cuenca, aumentadas con los sucesos más notables acaecidos en sus pontificados y con muchas curiosidades referentes a la Santa Iglesia Catedral y su cabildo y a esta ciudad y su provincia, Cuenca, 1860 (ed. fac-símil, Cuenca, Diputación Provincial, 2002), pp. 138-139.

63 Reunidos en las casas del concejo el guarda mayor de la ciudad y 24 regidores, «juntados a vos de pregón», se decidió otorgar la cesión del «sitio en el río de Xúcar, donde Garçi Álvares de Albornos tenía començado a faser un molino del Açena», de madera, Cuenca, 7 septiembre 1411, AHPC, Pergaminos, n. ${ }^{\circ} 130$ y SÁNCHEZ BENITO, J. M.", El espacio urbano de Cuenca en el siglo XV, ob. cit., p. 63.

64 Cabañas GonzÁlez, M. ${ }^{a}$ D., La caballería popular en Cuenca durante la baja Edad Media, Madrid, 1980 , p. 67. 
ferencia de sugerencias reales ${ }^{65}$. Durante el siglo XIV observamos como procurador en Cortes a miembros del linaje Albornoz. Así, Álvaro de Albornoz representó los intereses de Cuenca en 1322 como procurador ${ }^{66}$.

\subsection{Relaciones de poder con la iglesia}

La nobleza castellana medieval encontró en la carrera eclesiástica una salida para sus aspiraciones económicas, especialmente los miembros segundones de los linajes. En Cuenca ambos estamentos, el nobiliario y el eclesiástico, tuvieron unas fluidas relaciones, tanto en los asuntos conflictivos como en el ámbito de la cooperación, atisbando en el horizonte el partidismo hacia el monarca de turno o hacia el beneficio propio ${ }^{67}$. También podemos observar una intensa interacción del linaje Albornoz en el terreno económico como censatarios o arrendatarios de determinados bienes.

La primera noticia relacionada con el cabildo catedralicio, muestra a García Alvarez de Albornoz acusado junto a los nobles don Juan Manuel y Rodrigo Jiménez de Mesna por haber usurpado algunos de los bienes de la mesa episcopal dejados años atrás por el difunto obispo de Cuenca don Pascual. La familia Albornoz se encontraba entre los gestores de los bienes que la mesa episcopal había recibido durante la sede vacante y que la cámara pontificia reclamaba como suyos. Garci Álvarez en 1324 había prestado al obispo don Esteban la suma de 15.000 mrs., aunque las deudas parecen ser recíprocas y no muy claras, pues años después don Gil devuelve 1.000 mrs. que su padre a la hora de su muerte adeudaba a la mesa capitular del cobro del diezmo de Cañizares y Aldehuela ${ }^{68}$. El 23 de marzo de 1333 el papa Juan XXII comisionó al deán de Albarracín, a Andrés Sánchez, canónigo de la misma iglesia, y a los oficiales de Albarracín para que prestasen ayuda al cabildo catedralicio conquense contra ellos ${ }^{69}$.

El personaje de mayor relevancia del linaje que estudiamos fue Gil Álvarez de Albornoz, nacido en Cuenca, quien llegó a ser arzobispo de Toledo y cardenal a mediados del siglo XIV. Previamente, en el ámbito conquense, fue arcediano Huete y ostentó alguna canonjía en Cuenca, e incluso fue elegido como obispo de Cuenca en 1325 y 1326 por el cabildo catedralicio, pero no fue aceptado por el papa Juan XXII, que alegó razones de

65 Los caballeros de la baja nobleza, incluso algunos miembros de altos linajes, se encontraban representados en Cortes tanto en el brazo nobiliario como en el popular, Mitre FERnández, E., «La nobleza y las Cortes de Castilla y León», Las Cortes de Castilla y León en la Edad Media, II, Valladolid, 1988, pp. 74-76. La participación en Cortes era un privilegio que permitía tratar con el Consejo Real una serie de asuntos particulares que preocupaban a cada ciudad, al margen de las decisiones comunes que adoptase el monarca con los procuradores del reino, Olivera Serrano, C., «La participación de Cuenca en las Cortes de Castilla bajo el reinado de Enrique IV (1454-1474)», I Congreso de Historia de Castilla la Mancha, VI, Toledo, 1988, pp. 229-231.

66 SÁnchez Bentto, J. M. ${ }^{\text {, }}$ Las tierras de Cuenca y Huete en el siglo XIV. Historia económica, ob. cit., p. 65 .

67 DíAz IbÁÑEZ, J., «Las relaciones Iglesia-nobleza en el obispado de Cuenca durante la baja Edad Media», En la España Medieval, 20 (1997), pp. 281-319.

68 Chacón Gómez-Monedero, F. A., ««Este es el libro de cómmo se deben pagar las debdas para quitar la eglesia» de Cuenca del entredicho pronunciado por el papa Juan XXII», Espacio, Tiempo y Forma. Serie III. H. ${ }^{a}$ Medieval, 10 (1997), p. 50.

69 Ibidem, p. 282. 
edad y órdenes ${ }^{70}$. A pesar de ello, don Gil realizó diversas donaciones al cabildo catedralicio conquense, mientras ostentaba la mitra toledana y en sus mandas testamentarias ${ }^{71}$. De la misma familia, García Álvarez de Albornoz era deán de Cuenca en 138872. También conocemos al capellán de doña María de Albornoz, Juan Martínez de Salmerón, que figura como testigo en un pleito entre las villas de Tragacete y Beteta contra la ciudad de Cuen$\mathrm{ca}^{73}$, y la compra por parte del obispo Álvaro Martínez de unas casas a Juan de Albornoz, situadas cerca de la Puerta del Postigo ${ }^{74}$.

Garci Álvarez de Albornoz, que a principios del siglo XV era guarda mayor de la ciudad, entabló numerosos acuerdos o traspasos económicos con el deán y el cabildo catedralicio conquenses. En 1413 recibió a censo enfitéutico y perpetuamente un solar y edificio para él y para sus hijos y herederos. García Álvarez debía pagar anualmente, hasta San Juan de junio, un censo de 100 mrs. de la moneda corriente ${ }^{75}$. Un año después incluso fue a suplicar al papa Benedicto XIII ciertas posesiones que tenía en la villa de Huete; el pontífice le dio una carta para el obispo en que se las mandaba dar a censo por 10 florines cada año para la mesa del obispo. Los bienes eran unos molinos en Montalbillo y Huete, un solar de tierra, otra casa y su heredad llamada El Valle en término de Huete, una cueva que estaba en Huete «con dos cubas de fasta nouenta cántaros y çinco aloncodas de parrales» en Ballesteros, lugar de Huete ${ }^{76}$. En 1416 Garci Álvarez de Albornoz dio y pagó 10 florines de oro a Gil Fernández de Nuévalos, vicario de Iniesta y mayordomo del obispo de Cuenca, del censo de la casa que tenía en Gasconilla por el año $1415^{77}$.

70 DíAZ IBÁÑEZ, J., «El poder episcopal en la Diócesis de Cuenca durante la Edad Media», Espacio, Tiempo y Forma. Serie III. H. ${ }^{a}$ Medieval, 9 (1996), p. 43 y CHACón GómEZ-Monedero, F. A., ««Este es el libro de cómmo se deben pagar las debdas para quitar la eglesia» de Cuenca del entredicho pronunciado por el papa Juan XXII», ob. cit., p. 49.

71 «El 10 de septiembre de 1348, siendo arzobispo de Toledo, don Gil donó al cabildo de Cuenca la parte que le correspondía en los molinos de Mariana y 8000 mrs., con cargo de que rezasen por el alma de sus padres, la salud del rey y la suya propia. En su testamento, otorgado el 29 de septiembre de 1364, el cardenal se mostraría ampliamente generoso con el capítulo conquense, haciéndole las siguientes donaciones: unos molinos en el Júcar, cerca de la ciudad, que tiempo atrás había comprado a Miguel Sánchez; la llamada dehesa del Hendibo, para la dotación de dos capellanías perpetuas por su alma y la de sus padres en la capilla familiar de la catedral conquense donde estaban enterrados estos últimos; un cáliz de plata dorada, de tres marcos de peso, una pequeña cruz y dos casullas, una blanca y otra colorada jaspeada, con sus albas, amitos, estolas, manípulos y cíngulos, todo ello para dicha capilla familiar; una cabeza de plata, de cuarenta y ocho marcos de peso, con las reliquias de San Blas, y su mejor pluvial, de factura inglesa, lo cual nunca podrá ser enajenado por el cabildo, sino guardado en la sacristía junto con las demás joyas y reliquias, debiendo ser utilizado únicamente en determinadas fiestas solemnes y bajo ciertas condiciones; finalmente, deja establecido que se restituyan al cabildo una Biblia manual y unos comentarios de Santo Tomás sobre San Lucas y San Juan que el capítulo conquense le había prestado», ibidem, p. 308.

72 Ibidem, nota 90, p. 302

73 Alcocer, 13 mayo 1435, AMC, leg. 120, exp. 3, fol. 5r.

74 MuÑoz y Soliva, T., ob. cit., p. 130. La compra debió realizarse antes de 1389, fecha del fallecimiento de Juan de Albornoz.

75 Cuenca, 3 abril 1413, A(rchivo) C(apitular) (de) C(uenca), Secretaría, Actas Capitulares, Libro II, fol. 6v.

76 Cuenca, 14 noviembre 1414, ACC, Secretaría, Actas Capitulares, Libro II, fols. 65v-66r. En la carta del papa, emitida el 12 de octubre de 1414 y que le fue «reçibida benigna e graçiosamente», se especificaban las posesiones: «molendina de Montaluillo; molendinum in villa obtensi; domus de valle in terra obtensi; hospicium in villa obtensi; vna cueua in cadeni villa, quinque arancade de vineys in loco de Balesteros».

77 Cuenca, 4 octubre 1416, ACC, Secretaría, Actas Capitulares, Libro II, fols. 146v. 
Garci Álvarez de Albornoz, «de su propia e libre voluntad», hizo donación en 1417 al cabildo catedralicio de un solar que tenía «en fondo de la puerta del Postigo, junto con la torre e muro de la çibdat, para que sean tenidos de rogar a Dios por su vida e estado e de sus bienfechores». Así, de las dos carnicerías que Garci Álvarez tenía en la puerta del Postigo, a dos florines de censo anual por el solar, no debían pagar él y sus herederos más de un real de plata o la moneda que lo valiera, al mismo plazo que tuviera antes. Además, Garci Álvarez no debía pagar más de 60 mrs. de moneda corriente por las carnicerías $^{78}$. El noble conquense hizo juramento en 1418 de dar al camarero y canónigo Juan González de Frómista los maravedís que montaban quince almudes de cebada a razón de 12 mrs. la fanega, en el plazo de un mes. Como esta obligación no se cumplió, el vicario general, Juan Alfonso, obligó a Garci Álvarez de Albornoz a pagar a Benito Fernández, racionero, 700 mrs. que le prestó Juan González «en el plazo que va hasta la Pascua del Espíritu Santo» ${ }^{79}$. Un año después Garci Álvarez de Albornoz debió hacer frente al pago de 300 mrs. por las costas que había hecho, reclamadas por Alfón Martínez de Valverde, y en 1420 se obligó

con sus bienes e seguro a buena fe, sin mal engaño por dar e pagar a don Pedro Fernández, maestre escuela de la iglesia de Cuenca, absente, dos cahíces de trigo y un cahiz de cebada, que había recibido prestado por le faser plaser e puestos en su casa hasta el mes de agosto,

so pena de tres de pan por cada día demás que pasara ${ }^{80}$.

Otros miembros del linaje también otorgaban su protección al cabildo catedralicio conquense. María Álvarez de Albornoz introdujo en 1419 un codicilo en su testamento concediendo la extensa dehesa de Valsalobre, en la Sierra de Cuenca, al cabildo para la dotación de una capellanía perpetua en la catedral conquense, que debería ser cantada en la capilla familiar de los Albornoz ${ }^{81}$.

78 Cuenca, 28 agosto 1417, ACC, Secretaría, Actas Capitulares, Libro II, fols. 172r-v.

79 Garci Álvarez de Albornoz constituyó como fiador a Pedro López de Villanueva, «castellero», Cuenca, 18 octubre 1418, ACC, Secretaría, Actas Capitulares, Libro III, fol. 20v y Cuenca, 4 marzo 1419, CHACón Gómez-Monedero, F. A., Carrasco Lazareno, M. T. y Salamanca López, M., ob. cit., doc. 209, p. 97.

80 Cuenca, 8 abril 1419 y 12 junio 1420, ACC, Secretaría, Actas Capitulares, Libro III, fols. 45r y 97v.

81 DíAz IBÁÑEZ, J., «Las relaciones Iglesia-nobleza en el obispado de Cuenca durante la baja Edad Media», ob. cit., p. 309. El linaje aragonés de los Luna, vinculado a los Albornoz, realizó algunas donaciones al cabildo conquense. Doña Teresa de Luna, tía de don Álvaro de Luna y prima de doña Teresa Carrillo, otorgó en su testamento de 1430, entre otras, las siguientes mandas: 1500 mrs. anuales al cabildo catedralicio para dos aniversarios, y otros 1500 mrs. para una capellanía perpetua en la capilla de los Albornoz de la catedral de Cuenca, situados en la dehesa de la Muela de Pancrudo, en la Sierra conquense; también mandaba ser enterrada en dicha capilla de los Albornoz, en la sepultura donde yacía su tía doña Urraca de Albornoz, y con el hábito de Santa María de La Merced, ibidem, p. 309. 


\section{EL DOMINIO SEÑORIAL DE LOS ALBORNOZ EN EL SIGLO XIV}

\subsection{Creación del patrimonio territorial conquense albornociano}

El linaje Albornoz alcanzó un dominio señorial importante en el territorio conquense, marcando en forma de arco sus posesiones en la Alcarria y en la Sierra, en un sector colindante con los espacios comunales de la ciudad de Cuenca y con gran valor ganadero ${ }^{82}$. En el primer cuarto del siglo XIV Alfonso XI donó a García Álvarez de Albornoz las villas de Torralba y Tragacete con sus castillos, junto a Poyatos, Uña, Las Majadas, Beamud, Portilla, Valsalobre y Valdemeca. Después Álvar García de Albornoz compró Beteta con sus siete aldeas a Leonor de Guzmán - que la había recibido de Alfonso XI- y, por último, Micer Gómez García compró las villas del Infantado en 1371. A mediados de la centuria este personaje también guardó provisionalmente la villa de Pareja y su alcázar. La confirmación de la compra de Beteta era así reconocida por Enrique II:

Por razón que el rey Alfonso mi padre, que Dios perdone, a la sazón que estaba en el real de sobre Gibraltar, para cumplir sus menesteres que tenía en la conquista de la dicha cerca, vendió a doña Leonor, mi madre, que Dios perdone, por cierta cuantía de maravedís, el aldea de Beteta e la torre del dicho lugar, que es en término de la ciudad de Cuenca, con todos sus términos e vasallo, e con el señorío e jurisdicción e justicia civil e criminal, alta e baja, e mero e mixto imperio, e con todos los pechos e derechos, fonsado e fonsadera e portazgo e martiniega e yantares e escribanía e pedidos e otros pechos e derechos e tributar cualesquier foreros e no foreros, usados e por usar, así reales como concejiles, e con montes e ríos e aguas e prados e pastos [...]. E después de esto, la dicha nuestra madre vendió el dicho lugar de Beteta e la dicha torre con todos sus términos e rentas e pechos e derechos e con todas las otras cosas sobredichas, según que ella lo había comprado del dicho rey nuestro padre, a vos, don Alvar García de Albornoz, nuestro vasallo e nuestro mayordomo mayor, por cierta cuantía de maravedís que por ella le disteis e pagasteis ${ }^{83}$.

Los derechos, rentas y facultades del señorío jurisdiccional de las villas de los Albornoz vienen recogidos en la documentación que los concedía o confirmaba. Entre los derechos y facultades jurisdiccionales y de gobierno disfrutaban del ejercicio de la justicia en las villas, podían nombrar alcaldes, alguaciles, escribanos y otros oficiales de justicia y del concejo; podían devengar tasas de las escribanías de las villas y del propio ejercicio jurisdiccional; y podían obligar a los vecinos a cumplir cartas y mandatos del señor.

Entre los derechos tributarios derivados del vasallaje se encuentran el servicio y pedido, la fonsadera, el yantar y la posada, la cabeza del pecho de los judíos, el portazgo y

82 SÁnchez Bentto, J. M.', Las tierras de Cuenca y Huete en el siglo XIV. Historia económica, ob. cit., p. 21.

83 Alcalá de Henares, 29 junio 1370, publ. Moxó, S. de, ob. cit., pp. 68-69. 
almojarifazgo y el diezmo y montazgo — ambos tributos sobre el tráfico ganadero-. Los bienes y derechos de dominio solariego eran las heredades y posesiones de explotación directa o a través de arrendatarios, las rentas de pechos territoriales como la martiniega, el derecho sobre montes, prados, pastos, dehesas y ríos y sobre los términos por poblar - como el diezmo de la madera - ; y los derechos disfrutados sobre las salinas de Tragacete $^{84}$.

García Álvarez de Albornoz adquirió seis yugadas de terreno cerca de Tragacete en el primer tercio del siglo XIV y, después de 1338, el comendador Fernán Gómez de Albornoz hizo lo propio con el término de Cotillas, la torre de Buenache y la heredad de Aceña Álvar García de Albornoz recibió, como recompensa a su apoyo enriqueño, cien excusados en 1370 y la renovación de todas las concesiones territoriales anteriores ${ }^{85}$.

Fernán Gómez de Albornoz, comendador de Montalbán, en la década de 1370 cedió una casa y heredad en Sotoca. En 1394 su sobrina Urraca Gómez, mujer de Gómez Carrillo, realizaba un cambio, dando por aquella heredad — insuficiente para el pago de dos capellanías - , la dehesa del Vasallo en la sierra de Cuenca, inmediata al territorio de Tragacete y comprada años antes por García Álvarez de Albornoz. Unas décadas antes, el cardenal Gil de Albornoz y sus hermanos Álvar García y Fernán Gómez donaban los molinos del Castellar y una heredad en Chillarón, comprados previamente en aras de sus pretensiones expansivas por el entorno territorial conquense.

El cabildo catedralicio realizó dos trueques pactados con García Álvarez de Albornoz. En 1314, a cambio de sendas casas en Cuenca, aportó a los clérigos tierras que aquel había comprado en Las Zomas. Por el segundo, de mayor valor, el cabildo se deshizo de los heredamientos con pozos de sal de Valsalobre y Beamud, recibiendo en compensación tierras en Arquillos y su término, cerca de la ciudad. Esto indica la gran potencialidad expansiva de la nobleza en esta época, que buscaba el interés ganadero, la garantía de buenas rentas y cosechas y la rápida salida comercial de los productos de los terrenos circundantes a Cuenca. Además, también se hizo con algunas heredades en las salinas de Tragacete y Monteagudo ${ }^{86}$. Alfonso XI, como consecuencia de la enajenación de explotaciones a favor de la Corona contemplada en el Ordenamiento de Alcalá, autorizó el pago a Alvar García de Albornoz de 8.000 mrs. cada año para satisfacerle por la salina de Monteagudo, además de otros 2.900 mrs. y veinte cahíces de sal por las de Tragacete, ambas contempladas en la disposición de 1338. García Álvarez de Albornoz prestó 15.000 mrs. al obispo de Cuenca, quien se los devolvió en dos pagos independientes de 10.000 y 5.000 mrs., respectivamente, en 1324; también hay un testimonio de empréstito con

84 Moxó, S. de, ob. cit., pp. 45-46. En la compra de Beteta se pueden observar los derechos adquiridos, ibidem, pp. 68-71.

85 SÁnchez Bentto, J. M. ${ }^{a}$, Las tierras de Cuenca y Huete en el siglo XIV. Historia económica, ob. cit., pp. 66 y 71.

86 Ibidem, 138-139, 151, 178 y Moxó, S. de, ob. cit., pp. 31 y 36-37 y 178. 
el judío mosén Michaen, a quien debían 7.300 mrs. ${ }^{87}$; la judería conquense persistió, al menos, hasta $1391^{88}$.

Fernán Gómez de Albornoz logró que Alfonso XI confirmara una carta de Fernando IV en la que concedía al concejo de Cuenca y sus aldeas la exención de pagar portazgo salvo en Toledo, Sevilla y Murcia, privilegio adquirido en tiempos de Alfonso X y Sancho IV, porque «los pendran por los portadgos e por otras cosas e les toman todo quanto les falan, sin razón e sin derecho, e non deviéndoles ninguna cosa nin aviendo razón por que ge lo fazer» ${ }^{89}$.

Fernán Gómez de Albornoz solicitó la confirmación de unas cartas de Pedro I y Alfonso XI que confirmaban a los herederos de Gonzalo Rodríguez la donación del término de Cotillas hecha por el concejo de Cuenca en $1338^{90}$.

Entre otros testimonios posteriores, encontramos la queja de Constanza de Villena a la reina Leonor en la que exponía que había montarazes que quitaban los ganados y prendían a los hombres y las bestias de Valdeolivas, Alcocer y Salmerón - lugares suyos y de su hijo Juan de Albornoz - cuando los hallaban en su término paciendo o sacando pan o leña. Algo parecido ocurría con los lugares de los hijos de Gutierre Díaz de Sandoval y de los herederos de Alfonso Muñoz, que también pertenecieron a la jurisdicción de la villa de Huete y eran en ese momento de señorío ${ }^{91}$. Estas disputas fueron frecuentes entre la ciudad de Cuenca y, especialmente, los lugares de señorío de la Sierra.

A comienzos del siglo XV continuaban los intercambios de propiedades entre los Albornoz y el cabildo catedralicio. Doña Urraca Gómez de Albornoz dejó dos heredades para la maitinada de la Santa Iglesia de Cuenca en el lugar de Arcos de la Sierra, cuyo apeo se realizó en $1402^{92}$. La dehesa de Valsalobre, situada en la Sierra de Cuenca, volvió

87 SÁnchez Benito, J. M. ', Las tierras de Cuenca y Huete en el siglo XIV. Historia económica, ob. cit., pp. 179, 193 у 196.

88 Entre la abundante bibliografía que aborda la investigación de los judíos en el reino castellano, destacamos algunos trabajos sintéticos: CANTERA MonTENEGRo, E., «La imagen del judío en la España medieval», Espacio. Tiempo y Forma, Serie III, Historia Medieval, 11 (1998), pp. 37-64; «La historiografía hispano-hebrea medieval», Espacio. Tiempo y Forma, Serie III, Historia Medieval, 15 (2002), pp. 11-76; Moreno KocH, Y. e IzQuierdo BEnito, R. (eds.), Del pasado judío en los reinos medievales hispánicos. Afinidad y distanciamiento, Universidad de Castilla-La Mancha, 2005. Para el ámbito conquense no existen investigaciones monográficas sobre los judíos, aunque sí trabajos sobre la realidad conversa en la ciudad de Cuenca, como los de PÉREZ Ramírez, D., «La sinagoga de Cuenca, Iglesia de Santa María la Nueva», Cvenca. Rev. de la Excma. Dip. Prov., 19-20 (1982), pp. 47-78 y «Orígenes de la Inquisición en Cuenca», en Cuenca y su territorio en la Edad Media, ob. cit., pp. 399-410; Moreno Koch, Y., «El cementerio judío de Cuenca», I Congreso de Historia de Castilla La Mancha, ob. cit., VI, pp. 257-259; LoREnZo CADARSO, P. L., «Esplendor y decadencia de las oligarquías conversas de Cuenca y Guadalajara. Siglos XV y XVI», Hispania, LIV/186 (1994), pp. 53-94.

89 León, 12 noviembre 1311 y Sevilla, 20 abril 1346, AMC, leg. 2, exps. 7 y 19, publ. Colección..., ob. cit., docs. 47 y 66, pp. 157-158 y 184-185. El concejo conquense argumentaba que «por esta razón que se yerma Cuenca e su término».

90 Valladolid, 12 octubre 1351, AMC, leg. 107, exp. 1, publ. Colección..., ob. cit., doc. 87, p. 226. Esta confirmación fue realizada durante la sesión de Cortes reunida en Valladolid.

91 Valladolid, 20 noviembre 1410, RAH, Salazar y Castro, M-9, fol. 310 r-v.

92 Cuenca, 29 mayo 1402, SANZ y DíAZ, C., ob. cit., doc. 599, p. 68. 


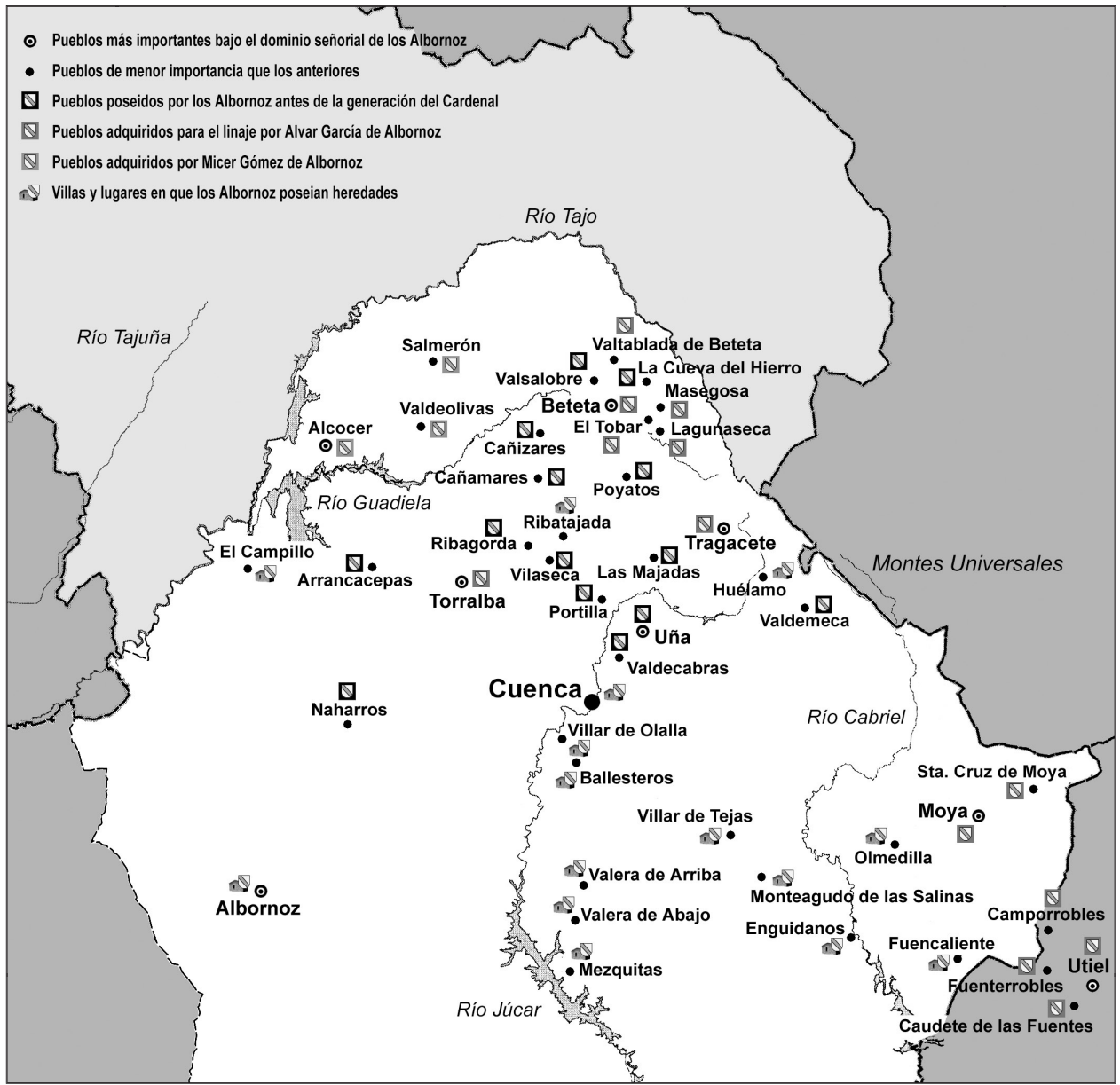

Dominio señorial del linaje Albornoz en los siglos XIV y XV.

a la titularidad de la Iglesia catedral años después, cuando María Álvarez de Albornoz la cambió por una capellanía perpetua en la capilla de su linaje $\mathrm{e}^{93}$.

\subsection{Actividades económicas: interés ganadero y aprovechamiento agrícola}

Aunque las actividades agrícola y ganadera tendieron a complementarse, en el caso conquense hubo una clara prioridad hacia la segunda por su mayor rendimiento económico, especialmente constatado durante el siglo Xv. El protagonismo en el desarrollo gana-

93 Cuenca, 17 abril 1420, ibidem, doc. 643, p. 72. El acuerdo capitular se había producido el 2 de agosto de 1418 y en él se insertaba la cláusula de doña María Álvarez de Albornoz, mujer de Juan Alonso de la Cerda. 
dero es una característica destacable del proceso de renovación nobiliaria en la Castilla bajomedieval. La nobleza obtenía rentas ganaderas de forma legítima - posesión de rebaños en propiedad que les otorgaba ciertos derechos y privilegios - o de forma irregular - control de dehesas y baldíos, robos de ganado, usurpación de tierras - ${ }^{94}$. Los distintos linajes conquenses demostraron gran interés hacia el arrendamiento de dehesas y pastos para el ganado como fuente de ingreso y en la práctica especulativa sobre la ganadería a través de la trashumancia. El pastoreo fue una actividad económica importante en la tierra de Cuenca durante la baja Edad Media, aunque no exclusiva ni siquiera en las áreas abruptas de la Sierra; la actividad pastoril, preferente, compartió protagonismo con los usos forestales - extracción de madera y carbón, práctica cinegética y recolectora - y la agricultura de rozas $^{95}$. De todas formas, parece ser que en el caso de Cuenca existió predominio del propietario pequeño y mediano, a pesar de que la ganadería constituía una base económica prioritaria para la nobleza territorial ${ }^{96}$.

Los Albornoz fueron el primer linaje de la nobleza territorial con intereses en la próspera ganadería conquense. Los ganaderos de las comarcas de Molina y Cuenca llevaban a pastar sus ganados a la zona meridional del Sistema Ibérico y aprovechaban su estancia para realizar algunas ventas. En 1328 García Álvarez de Albornoz llevó a pastar a término de Albarracín unos 2.000 carneros junto a otros ganados mayores y menores, de los que una parte vendió a crédito a diversos carniceros aragoneses. Estos se negaron a satisfacerle las cantidades por las que se habían comprometido en los contratos notariales, alegando que ellos habían intervenido usuras, o amparándose en privilegios de concesión de moratoria de pago emanados del rey de Aragón. Este mismo año García Álvarez de Albornoz había vendido otros mil carneros en el lugar de Huélamo a unos carniceros de Villafranca ${ }^{97}$. Gonzalo Fernández de Heredia, que era alcaide y baile de Albarracín, tomó 50 cabezas de este rebaño en Vegas, una aldea de Albarracín, bajo el pretexto de que debían pagar «montático». García Álvarez de Albornoz presentó un recurso ante Pedro IV manifestando que los carneros habían sido vendidos en Huélamo e iban por camino público, por lo que no estaban obligados a pagar dicho impuesto.

Durante la primera mitad del siglo XIV García Álvarez de Albornoz y posteriormente su hijo Ferrán Gómez fueron alcaldes del castillo de Huélamo «a pennos por una quantía

94 Quintanilla Raso, M. ${ }^{\text {a }}$ C., «La renovación nobiliaria...», ob. cit., p. 276. GeRBET, M.-C. ha sistematizado la relación entre nobleza y ganadería durante los siglos xIV y xv, en los que la nobleza supo aprovechar la crisis económica y demográfica para desarrollar la ganadería, «Noblesse et élevage dans la Couronne de Castille a la fin du Moyen Âge», La nobleza peninsular en la Edad Media, ob. cit., pp. 189-190 para el caso de Cuenca.

95 Una visión de conjunto sobre el tema en el trabajo de QUINTANILLA RASO, M. ${ }^{\mathrm{a}} \mathrm{C}$., «El pastoreo en Cuenca a fines de la Edad Media. Bases y lógicas de un sistema económico en la compleja realidad agraria», GómEZPantoja, J. (ed.), Los rebaños de Gerión. Pastores y trashumancia en Iberia antigua y medieval, Madrid, 2001, pp. 37-69.

96 SÁnchez Pablos, C., «Los propietarios de ganados en la Baja Edad Media: el ejemplo de Cuenca», Actas I Simposio de Jóvenes Medievalistas. Lorca 2002, ob. cit., pp. 189-199.

97 DiAgo Hernando, M., «El comercio de productos alimentarios entre las Coronas de Castilla y Aragón en los s. XIV y XV», Anuario de Estudios Medievales, 31/2 (2001), pp. 614-616. Este autor identifica el topónimo Villafranca con Villafranca del Penedés, lo que probaría la existencia de una exportación de ganados castellanos al principado de Cataluña, más alejado territorialmente que el reino de Aragón. 
de maravedís», porque pertenecía a la orden de Santiago. En ese intervalo de tiempo habían cobrado el derecho de asadura que el rey Alfonso XI había concedido a los comendadores del castillo de Huélamo, por el paso de ganados del concejo de Cuenca hacia la sierra. El concejo de Cuenca mantuvo un pleito contra el maestre de Santiago que abarcó los reinados de Enrique II y Juan I, en el que se exponía que García Álvarez de Albornoz comenzó a llevar la asadura hacia 1321 «más por fuerça que por derecho, e que después el conçejo de la dicha çibdat, conosçiendo los buenos debdos que avía con el dicho Garçía Álvarez e las buenas obras quel dicho conçejo dél ovieran reçebido que le fezieran graçia que llevase la dicha asadura en quanto él toviese el dicho castiello».

Su hijo Fernán Gómez, que disfrutó de la tenencia del castillo, entre 1339 y 1359 aproximadamente, pidió la misma gracia que el concejo de Cuenca había dado a su padre, porque «los pastores le non consintieron tomar la dicha asadura e ferieron a los hombres del castellero». Desde que Fernán Gómez se fue al reino de Aragón los ganados subían a la Sierra de Cuenca libremente, hasta que el comendador García Alfonso volvió a tomar la asadura en 1377, por lo que el concejo volvió a entablar el pleito. Una última noticia relacionada con la actividad ganadera es el pago que hubo de realizar Garci Álvarez de Albornoz por el importe de 24 reses que había recibido del refitor capitular en $1419^{98}$.

La ocupación señorial de las tierras de Cuenca, en muchas ocasiones, se acompañaba del adehesamiento, para impedir la entrada y asegurarse su uso exclusivo, según hemos podido comprobar. Otras prácticas abusivas fueron el arrendamiento - conseguido mediante presión - de tierras, que finalmente se apropiaban, y la ocupación indebida de despoblados y términos comunales. Esta privilegiada situación jurisdiccional de los señoríos, con el consiguiente acrecentamiento económico y político, provocó durante el siglo XV no pocos éxodos de habitantes de Cuenca y su tierra hacia las villas señoriales ${ }^{99}$. El concejo de Cuenca protestó a la corte reiteradamente la huida de población pechera hacia «los logares de sennorío e de la obispalya», donde pretendían evitar sus obligaciones fiscales. Estos pecheros iban con sus mujeres e hijos y llevaban consigo todos los bienes muebles que tenían, abandonando sus heredades urbanas. Juan I concedió una merced al

98 Cuenca, 24 agosto 1419, Chacón Gómez-Monedero, F. A., Carrasco Lazareno, M. T. y SalaMANCA LóPEZ, M., ob. cit., doc. 352, p. 142. El refitor era el órgano que administraba los bienes del cabildo catedralicio.

99 Este análisis puede ofrecer determinados paralelismos con realidades geográficas distantes pero de connotaciones económicas similares, como el caso de la Sierra de Córdoba, CABRERA MuÑoz, E., «Usurpación de tierras y abusos señoriales en la sierra cordobesa durante los siglos XIV-XV», en Actas del I Congreso de

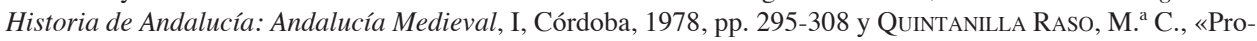
piedades y derechos en los señoríos nobiliarios cordobeses de la baja Edad Media. Nuevas interpretaciones», Historia. Instituciones. Documentos, 24 (1997), pp. 391-414. Para el caso concreto conquense, ver QuINTANILla RAso, M. ${ }^{a}$ C., «Los derechos sobre la tierra en el sector centrooriental de la Extremadura castellana. Usos y abusos a fines de la Edad Media», Meridies, 3 (1996), pp. 29-50 y los trabajos de OrTEGA CERvigón, J. I., «Usurpaciones de términos y abusos señoriales en la jurisdicción urbana de Cuenca a finales de la Edad Media», en Arízaga Bolumburu, B. y Solórzano Telechea, J. A. (eds.), Nájera. Encuentros Internacionales del Medievo. La ciudad medieval y su influencia territorial, Logroño, Instituto de Estudios Riojanos, 2007, pp. 221-238 y ««Porque la lauor de la Syerra es prouechosa para los pastos». Conflictos económicos, territoriales y jurisdiccionales entre el concejo de Cuenca y los vasallos de señorío (ca. 1450-1520)», En la España Medieval, 31 (2008), pp. 37-96. 
concejo conquense para que estos hombres y mujeres pagasen, aunque morasen en lugares de señorío, apremiando a los alcaldes de éstos para que lo cumpliesen ${ }^{100}$. Los abusos de poder de algunos señoríos asentados en la tierra de Cuenca se manifestaron desde finales del siglo XIV por la ocupación ilegal de tierras, especialmente en la Sierra, donde los Albornoz realizaron roturaciones, casas y pajares de forma irregular.

Un fenómeno muy habitual para delimitar el espacio fueron los apeos de términos entre el concejo de Cuenca y los señoríos limítrofes de la Sierra. En 1390 se renovaron los amojonamientos entre los límites de los términos de Cuenca con varios concejos de señorío ubicados en la Sierra conquense: Uña, Las Majadas, La Losilla, Poyatos, Beteta, Tragacete, Huélamo y Beamud ${ }^{101}$. Doña Constanza, viuda de Juan de Albornoz, y sus hijas eran las titulares del señorío de estos lugares salvo Beamud, que pertenecía a Gonzalo Fernández de Albornoz, Las Majadas, cuya señora era Elvira López, viuda de Ruy Díaz de Huérmezes, y La Losilla, que pertenecía a Francisco López de Huélamo, vecino de Cuenca. Estos lugares realizaban entradas en el término de la ciudad y, a veces, cambiaban de posición los mojones que indicaban los límites. La ciudad de Cuenca envió sus procuradores a estos lugares para delimitar los términos entre estas poblaciones y la Sierra, además de instar el corregidor conquense a devolver el pan que se sembrase dentro de los límites de la tierra de Cuenca ${ }^{102}$. En el apeo de Uña con Cuenca el mayordomo de doña Constanza, Pascual Sánchez, y el alcalde de la villa, Yáñez Gil, aun obedeciendo el mandato regio, dijeron que «en razón del ofiçio, que heran vasallos de doña Constança e de hijas de don Juan de Albornoz, e fasta no haver mandado della que non farían cosa alguna, que non serían osados». Los encargados por el concejo de Cuenca de realizar la delimitación de los términos, Marcos Sánchez y Adán López ${ }^{103}$, como «la dicha doña Constança avía seydo rebelde en no querer venir ni enviar procurador con su çierto poder», pidieron que tomaran juramento a «varios omnes antiguos del dicho logar Uña e que más sopiesen en hecho de los dichos términos», para determinar junto a los otros junteros el término entre la Sierra de Cuenca y Uña y ver y requerir el trazado de los mojones. Las señales más habituales que servían como mojones eran montones de piedra y cruces en árboles de algún paraje significativo ${ }^{104}$.

100 Briviesca, 9 junio 1386, AMC, leg. 3, exp. 15, publ. Colección..., ob. cit., doc. 122, pp. 287-288.

101 9-23 agosto, 16 y 23 septiembre 1390, AMC, leg. 34, exp. 1, publ. ibidem, docs. 131-134, pp. 301324.

102 El corregidor de Cuenca Fernando Martínez de Bonilla había sido nombrado por Juan I para dirimir estos amojonamientos, 9 mayo 1390, AMC, leg. 47, exp. 3, fol. 51r-v.

103 El concejo de Cuenca había dado, en principio, una carta de poder a Juan Sánchez de Jábaga y Adán López de Villanueva para que les representaran en la determinación de términos, Cuenca, 19 junio 1390, ibidem, fol. 53r-v. Un mes después el regidor Marcos Sánchez recibió tal cometido, Cuenca, 17 julio 1390, ibidem, fol. $52 \mathrm{v}$.

104 La descripción del trazado de los amojonamientos es muy minuciosa, efectuada por los junteros de la localidad, que conocían bien el terreno y su toponimia, como sucede en este paraje entre el término de Uña y la Sierra de Cuenca:

E luego vinieron a la dehesa que tienen amojonada e usaban guardar los de Uña, e comiença el primer mojón della en la çingla del Çello do está un pino alvar que tiene una cruz. E dende recude a las tajadas do está un mojón en un pedregal, çerca el camino que va de Uña a Valdecabras, e dende va al alto adelante fasta el mojón que está en el altyllo La Cañada. E dende recude a un pino seco que está en el altillo de ençima del llano en que está hecha una cruz antyguamente. E dende recude 
La sentencia del corregidor sobre Uña, Poyatos, Beteta y Tragacete, lugares de doña Constanza, dictaminó que no tenían privilegios o cartas sobre los términos y hallaba los mojones y determinaciones hechas por los junteros «bien puestas e verdaderas», pese a que Hernán Sánchez de Salmerón, procurador de doña Constanza, quiso mostrar ciertos recaudos sobre el rincón de Uña, unos mojones que según él debían ir por otro lado ${ }^{105}$.

\section{CONCLUSIONES}

Los Albornoz acumularon un gran patrimonio territorial en el obispado de Cuenca a lo largo del siglo XIV. La pujanza social de este linaje responde a la línea ascendente que la nobleza venía mostrando desde época de Alfonso X y a la aceleración de la movilidad social a la que asiste el grupo nobiliario con la dinastía Trastámara ${ }^{106}$. La posición política y económica de los miembros del linaje fue consolidándose por su condición de señores de Torralba y Beteta, villas encuadradas en las estribaciones de la Sierra conquense, y gracias también a sus intervenciones en los intereses concejiles de Huete y Cuenca y al desempeño de oficios cortesanos y administrativos, ambos rasgos distintivos de las pautas de actuación de la nueva nobleza que se forjó en el reino castellano durante la época trastamarista.

De igual forma, los Albornoz mostraron interés por las actividades ganaderas y agrícolas propias de la economía castellana bajomedieval. La extinción de la rama principal del linaje provocó la dispersión de su patrimonio, codiciado y repartido ente otras dos grandes familias nobiliarias conquenses, los Carrillo y los Mendoza.

el çerrillo ayuso a un teso de un pedregal que está un mojón de piedras çerca de un pino negral que hicieron una cruz e tiene una cortadura antygua. E dende recude el teso ayuso fasta el rostro de La Cañada e a donde están tres pinos en uno e están señalados antyguamente, e señaláranlos nuevamente. E dende recude [al teso] al mojón que está en el altyllo çerca del royo La Cañada, çerca de un pino negral que está señalado. En dende recude al teso que está otro mojón del royo La Cañada, e donde traviesa el royo La Cañada e recude al mojón que está fondo del villarejo la cañada El Çerrillo, está el mojón açerca de dos pinos, el uno mayor que el otro. E dende recude a otro mojón que está un teso çerca la senda que sale a la hoya Caltín. E dende recude el teso adelante e del camino arriba fasta el mojón que está çerca el carril que diçen de la Cajada Vieja e recude a hondón de la cueva El Rayo e da en Xúcar. E dende recude al camino adelante e del camino arriba royo pasado, e luego sale e recude al arenoso del fondón de la fuente El Hera e finca de fuera la fuente El Hera, e de las apartes de arriba pártelo la Çingla del Çello, fondonero del carril, donde dijeron que vieran guardar de commo pasa el vado de Uña para Valdecabras de la parte de hazia Cuenca, como dize lo labrado, fasta pasada la fontezilla de la Hoz del Juez que entra en Xúcar,

9 agosto 1390, publ. ibidem, p. 304.

105 El bachiller y corregidor Fernando Martínez Bonilla publicó la sentencia en el palacio del obispo Álvaro, en presencia de los procuradores de Cuenca y el procurador de doña Constanza, Cuenca, 23 septiembre 1390, AMC, leg. 47, exp. 3, fols. 63v-65r.

106 Gerbet, M.-C., Las noblezas españolas en la Edad Media. Siglos XI-XV, ob. cit., p. 167. 


\section{CUADRO GENEALÓGICO DE LOS ALBORNOZ Y CARRILLO DE ALBORNOZ, EN LOS SIGLOS XIV Y XV}

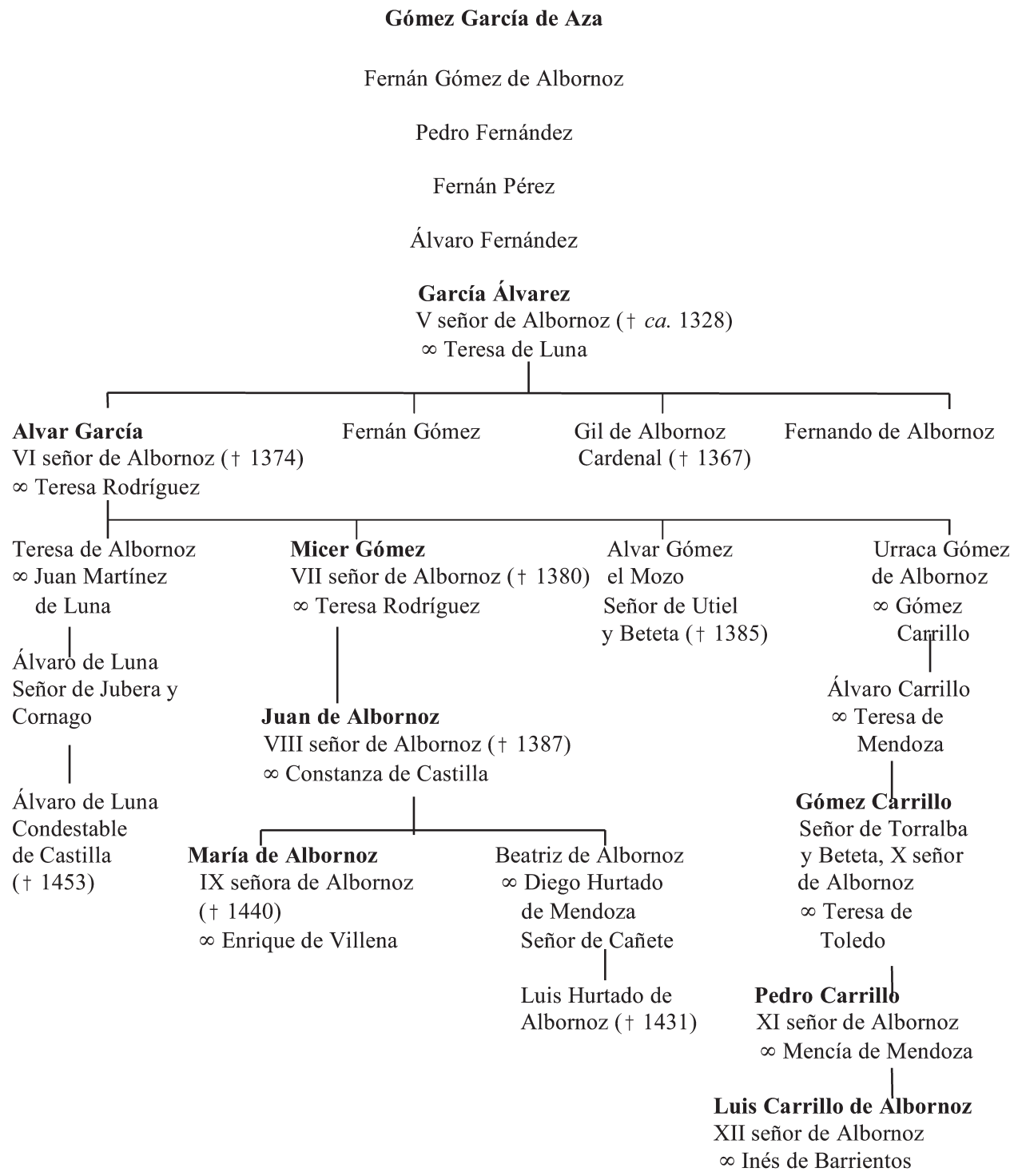





\title{
LOS LEPROSOS EN EL PORTUGAL DE LOS SIGLOS XIV Y XV: CONTRIBUCIÓN PARA UNA «HISTORIA DE LOS ASISTIDOS»
}

\author{
Rita Luis Sampaio Da Nóvoa ${ }^{1}$
}

\begin{abstract}
RESUMEN
La historiografía dedicada a la lepra, a los leprosos y a las leproserías en la época medieval ha desarrollado en las últimas décadas interesantes y innovadoras perspectivas de análisis. El trabajo enseguida presentado intenta explorar algunas de esas perspectivas aplicadas al caso portugués en los siglos XIV y XV. Entre varios aspectos, el principal objetivo es llamar la atención para la noción de leproso y para los diferentes factores que deben ser tenidos en consideración cuando el historiador piensa lo individuo enfermo. En realidad, la diversidad y complejidad de las situaciones verificadas exige no un abordaje simplista y general (leproso igual a excluido) pero una mirada que no deje de lado los aspectos que definen y caracterizan el leproso mas allá de la lepra.
\end{abstract}

Palabras clave: Siglos XIV-XV, Portugal, Lepra, Leprosos, Leproserías, «Historia de los asistidos».

\begin{abstract}
In the last decades the historiography dedicated to the study of leprosy, lepers and leperhouses in the Middle Ages has developed several innovative and interesting perspectives. The following article will explore some of them in relation to the portuguese scenario in the $14^{\text {th }}$ and $15^{\text {th }}$ centuries. Among other aspects, the main objective is to draw attention to the notion of leper and to the different factors that should be taken into consideration when the historian observes the sick individual. In fact, the diversity and complexity of the documented situations demands not a simplistic and generalist approach (leper as excluded) but a survey that doesn't exclude the characteristics that define the leper besides the leprosy itself.
\end{abstract}

Keywords: $14^{\text {th }}-15^{\text {th }}$ centuries, Portugal, Leprosy, Lepers, Leper-houses, «History of the Assisted».

Fecha de recepción: 25 octubre 2009. Fecha de aceptación: 22 diciembre 2009.

1 Faculdade de Ciências Sociais e Humanas. Universidade Nova de Lisboa. Portugal. Email: ritalsnovoa@yahoo.com. 